\title{
Levulinic Acid Biorefineries: New Challenges for Efficient Utilization of Biomass
}

Filoklis D. Pileidis and Maria-Magdalena Titirici ${ }^{*[a]}$

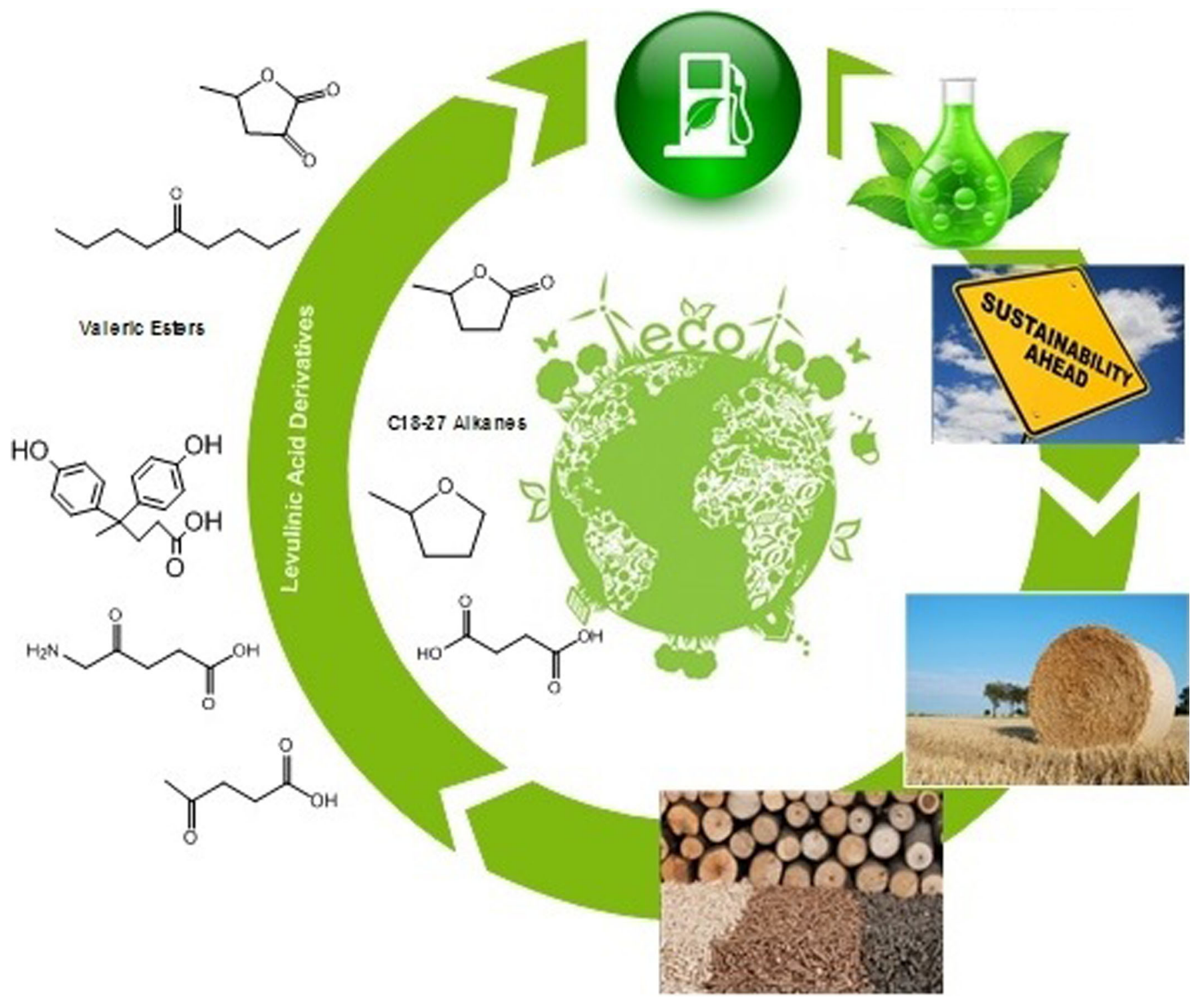


Levulinic acid is a sustainable platform molecule that can be upgraded to valuable chemicals and fuel additives. This article focuses on the catalytic upgrading of levulinic acid into various chemicals such as levulinate esters, $\delta$-aminolevulinic acid, suc- cinic acid, diphenolic acid, $\gamma$-valerolactone, and $\gamma$-valerolactone derivatives such valeric esters, 5 -nonanone, $\alpha$-methylene- $\gamma$ valerolactone, and other various molecular-weight alkanes $\left(C_{9}\right.$ and $\mathrm{C}_{18}-\mathrm{C}_{27}$ olefins).

\section{Introduction}

One of the greatest challenges that industry faces in the $21^{\text {st }}$ century is the transition from a fossil-fuels economy to one based on renewable resources with various economic, social, and environmental benefits: 1) environmentally beneficial reduction in the carbon footprint of chemicals and liquid fuels; 2) a more profitable agricultural economy; and 3) the substitution of existing products by alternatives that are safer and have a reduced environmental footprint, for example, biocompatible and biodegradable polymers. ${ }^{[1,2]}$

Biomass can be used as an alternative resource for fuels and chemicals production. ${ }^{[3]}$ Biomass is defined as any organic matter, including energy crops and trees, agricultural food, aquatic plants, wood and wood residues, animal wastes, and other waste materials. ${ }^{[4]}$ Lignocellulose is the key structural element of plants and is found in roots, stalks, and leaves. It is composed $^{[5]}$ of three major components: cellulose (38-50\%), lignin (15-30\%), and hemicellulose (23-32\%). Cellulose is a linear polymer of glucose linked by $\beta-1,4$ bonds. Hydrogen bonds occur between adjacent cellulose polymers chains that determine a crystalline structure that gives structural strength to the plants and that makes them particularly difficult to be attacked by enzymes. Cellulose can be converted into glucose through chemical or enzymatic hydrolysis ${ }^{[6,7]}$ and can be used to produce ethanol and platform chemicals, such as LA, 5-hydroxynethylfurfural (HMF), and liquid fuels. ${ }^{[8,9]}$ Lignin is a polymer formed out of phenylpropane units linked by ether bonds. Lignin acts as a glue for cellulose. The structure of lignin depends on the source of the biomass, if it is hardwood or softwood. Mainly, lignin is composed of three main precursors: $p$ coumaryl alcohol, coniferyl alcohol, and sinapyl alcohol. ${ }^{[10]} \mathrm{De}-$ spite the complexity of its structure, there are many examples in the literature to convert lignin into fuels and high-value chemicals. ${ }^{[11]}$ Hemicellulose is a highly branched polymer composed primarily of five-carbon sugars (mostly xylose). It is chemically bonded to lignin and serves as an interface between lignin and cellulose. ${ }^{[12]}$ Hemicellulose is usually used to produce xylitol, furfural, and furfural derivatives. ${ }^{[13,14]}$

Levulinic acid (also known as 4-oxopentanoic acid or $\gamma$-ketovaleric acid) has been classified by the United States Department of Energy as one of the top-12 promising building blocks

\footnotetext{
[a] F. D. Pileidis, Prof. M.-M. Titirici

School of Materials Science and Engineering

Materials Research Institute

Queen Mary University of London

Mile End Road, London, E58 HA (UK)

E-mail:m.m.titirici@qmul.ac.uk

(iD ORCID(s) from the author(s) for this article is/are available on the WWW under http://dx.doi.org/10.1002/cssc.201501405.
}

and is considered to be a promising organic intermediate for the synthesis of several chemicals for applications in fuel additives, fragrances, solvents, oil additives, pharmaceuticals, and plasticizers. ${ }^{[15-17]}$ Levulinic acid contains ketone and carboxylic acid groups. These two functional groups are important for the production of a wide range of chemicals ${ }^{[2]}$ such as levulinate esters, $\gamma$-valerolactone (GVL), acrylic acid, 1,4-pentadiol, angelica lactone, 2-methyltetrahydrofuran (MTHF), $\delta$-aminolevulinic acid (DALA), and so on (Figure 1).

The purpose of this paper is to provide a comprehensive review on the production of levulinic acid as a platform molecule and its utilization to produce various chemicals. The review will present different approaches and strategies that have been reported for catalytic levulinic acid conversion with focus on the manufacture of valuable bulk and platform chemicals for the chemical industry. The first part of this review will focus on LA derivatives (i.e., produced directly from levulinic acid), whereas the last part we will focus on the production of LA intermediates such as $\gamma$-valerolactone (GVL) and its further conversion into valuable chemicals and fuels.

\section{Production of Levulinic Acid from Lignocel- lulosic Biomass}

This part of the review will provide possible mechanisms for the transformation of carbohydrates and raw biomass into levulinic acid, according to current literature data. In the case of using cellulose as a biomass precursor, the first step in the process is the hydrolysis of cellulose into glucose monomers, followed by dehydration of glucose into $\mathrm{HMF}^{[20]}$ Under acidic conditions, the hydrothermal process allows effective conversion of D-glucose into HMF supported by the Lobry de BruynAlberta van Ekstein rearrangement, which implies that D-glucose isomerizes to $\mathrm{D}$-fructose and then undergoes dehydration to $\mathrm{HMF}^{[21]}$ During dehydration of the sugars, furfural is the main product obtained by pentoses, whereas HMF is generated by hexose dehydration. ${ }^{[20]}$ Levulinic acid is produced through the hydrolysis of HMF under acidic conditions. In the acid-catalyzed conversion of hexose sugars into levulinic acid, formic acid is coproduced as a low-value chemical used in the production of formaldehyde, rubber, plasticizers, pharmaceuticals, and textiles. ${ }^{[22]}$

Another process for the efficient conversion of lignocellulosic biomass into valuable chemicals and fuels is so-called hydrogenolysis, which results in cleavage of $\mathrm{C}-\mathrm{C}$ and $\mathrm{C}-\mathrm{O}$ bonds by hydrogen. This technology could allow the direct transformation of poly- and monosaccharides into established platform chemicals, including sugar alcohols glycols and even alkanes. ${ }^{[23]}$ In 2006, Fukuoka and Dhepe ${ }^{[24]}$ reported the hydrogenolysis of cellulose to sugar alcohols (yield of sorbitol: $31 \%$ ) 
over supported noble metal catalysts in the aqueous phase and under a hydrogen atmosphere to provide a very promising green route for cellulose conversion. Palkovits ${ }^{[23]}$ also mentioned the use of heteropolyacids (HPAs) combined with Rusupported catalysts to achieve high yields of $\mathrm{C}_{4}-\mathrm{C}_{6}$ sugar alcohols derived from cellulose. The high stability of sugar alcohols allows further degradation reactions to be avoided, such as hydrolysis of the sugars. Zhang et al. ${ }^{[25]}$ have presented Ni-promoted tungsten carbides and tungsten-promoted $\mathrm{Ni}$ catalysts as efficient systems; the former is supported on 3D mesoporous carbon and is the best system. However, the catalytic transformation of cellulose into key building blocks or platform chemicals such as HMF, levulinic acid, and lactic acid under mild conditions has attracted much attention in recent years, as these conversions can be operated without consumption of hydrogen or oxygen and thus are more economical than the hydrogenolysis or oxidation of cellulose.

Figure 2 shows a possible pathway for the conversion of biomass into levulinic acid.

Filoklis D. Pileidis studied chemistry at the Aristotle University of Thessaloniki (Greece). He obtained his MSc in Green Chemistry and Sustainable Industrial Technology, working with Prof. James Clark at the Green Chemistry Centre of Excellence, University of York (United Kingdom), in 2012. Since 2013, Filoklis has been working as a PhD student at the School of Engineering and Materials Science at the Queen Mary University of London (QMUL, United

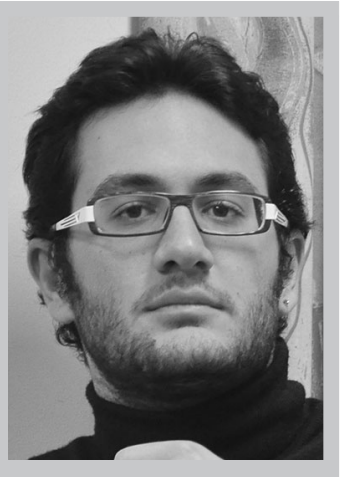
Kingdom), working under the supervision of Prof. Maria Magdalena Titirici. His PhD research involves the hydrothermal upgrading of lignocellulosic biomass into value-added chemicals (levulinic acid) and catalysts and the sustainable conversion of levulinic acid into levulinate esters for efficient utilization as fuel and food additives.

Magdalena Titirici obtained her $\mathrm{PhD}$ at the University of Dortmund, Germany. Between 2006 and 2012 she led the group "Sustainable Carbon Materials" at the Max Planck Institute of Colloids and Interfaces, Potsdam, Germany, where she also did her Habilitation. In 2013, Dr. Titirici became an Associate Professor in Materials Science at the Queen Mary University of London. She was promoted to full Professor in 2014. Dr. Titirici is the author of

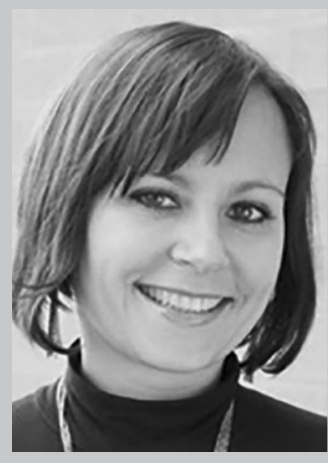
around 100 publications in the field of sustainable materials and green nanochemistry, several book chapters, and one edited book. Her research interests include porous materials, hydrothermal carbonization, innovative utilization of biomass and waste, biofuels, $\mathrm{CO}_{2}$ sequestration, electrocatalysis in fuel cells, and energy storage in secondary batteries and supercapacitors.
A well-known approach to convert lignocellulosic materials into bulk chemicals is treatment of the biomass with a mineral acid, such as sulfuric acid, at elevated temperatures (100$250^{\circ} \mathrm{C}$ ). Upon treatment, the hemicellulose and cellulose fractions of lignocellulosic materials are converted into soluble low-molecular-weight components. Extraction of levulinic acid from lignocellulosic biomass can be enhanced in the presence of a homogenous or heterogeneous catalyst in the reaction system. Homogeneous acids (e.g., $\mathrm{H}_{2} \mathrm{SO}_{4}, \mathrm{HCl}$, etc.) were used for a long time to synthesize levulinic acid. ${ }^{[26]} \mathrm{Cha}$ and Hanna ${ }^{[27]}$ have studied the effectiveness of dilute acids on the production of levulinic acid from sucrose. A number of investigations have also been performed to determine the effects of various processing conditions on reaction yields. ${ }^{[28]}$ According to this review, Chang mentions that reaction temperatures between 150 and $230{ }^{\circ} \mathrm{C}$, acid concentrations between 3.5 and $10 \mathrm{wt} \%$, and long reaction times normally lead to higher yields of levulinic acid. Extensive research on the production of LA from various biomass precursors under different catalytic conditions has been conducted by Raghavan et al. ${ }^{[29]}$ They mention the use of high-concentration mineral acids and long reaction times to achieve high yields of LA and the absence of HMF as an intermediate to undergo degradation of lignocellulosic biomass or monosaccharides. A summary of possible levulinic acid yields from different biomass feedstocks is reported in Table 1.

Although these hydrolysis reactions are effective, mineral acid is harsh and corrosive and promotes degradation of the used equipment. Besides, it is difficult to recover the acid catalyst from the reaction products for recycling purposes. ${ }^{[30,31]}$ As an alternative, heterogeneous acid catalysts have been used, as these catalysts can overcome the problems occurring in homogeneous catalysts. ${ }^{[32]}$ Heterogeneous catalysts represent a viable alternative to homogeneous catalysts and may offer an environmental advantage owing to their selective and easyto-handle nature, reduced equipment corrosion issues, and relatively low cost if the catalyst can be easily separated and recycled. ${ }^{[33]}$ Table 2 summarizes studies on the production of levulinic acid from different biomass feedstocks in the presence of solid heterogeneous catalysts. The drawbacks include low reaction yields, slow reaction rates, and prolonged reaction times to obtain reasonable quantities of levulinic acid. The highest yields (up to $43 \mathrm{~mol} \%$ ) of levulinic acid from fructose can be achieved with the use of the LZY zeolite catalyst. ${ }^{[4]}$ Alonso, Dumesic, and Horváth ${ }^{[34-37]}$ suggest alternative and efficient biobased solvents for the conversion of biomass feedstocks into LA such as GVL and tetrahydrofuran (THF). The use of GVL as a solvent provides significant advantages, as GVL is completely miscible with water and effectively solubilizes the biomass, which thereby eliminates the formation of solid deposits and simplifies separation steps, as GVL is a product of the process. This process allows sufficient utilization and conversion of both the cellulose and hemicellulose fragments, which eliminates the initial pretreatment-extraction steps, and allows additional solubilization and further degradation of lignin into typical low-molecular-weight products. ${ }^{[34]}$ The use of the monophasic THF/water solvent systems allows efficient conver- 

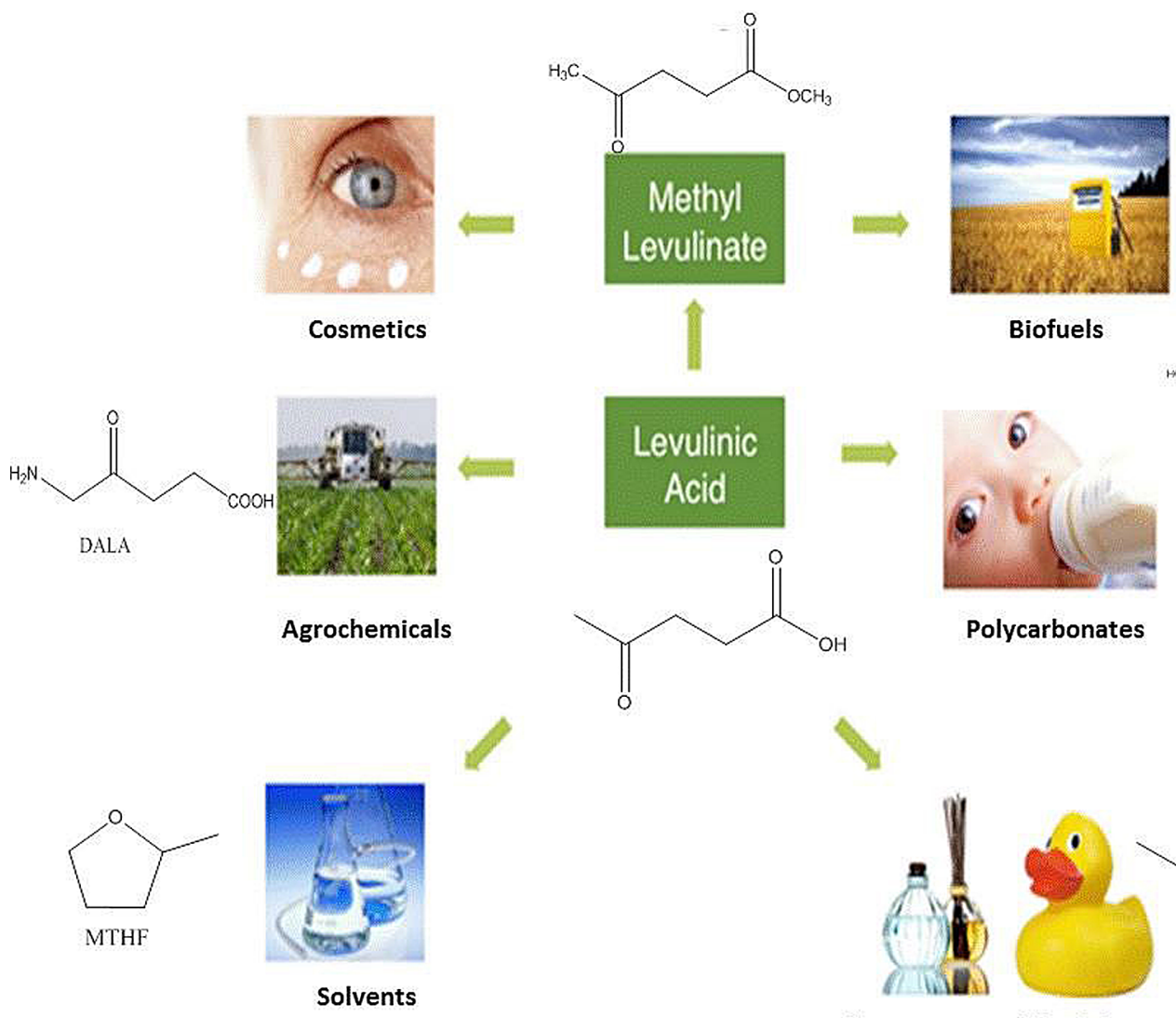

Biofuels

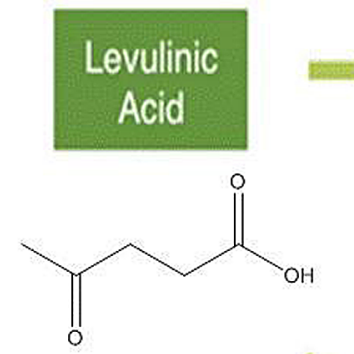

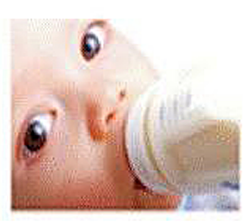

Polycarbonates

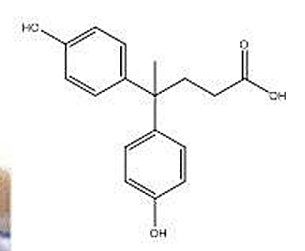

Diphenolic Acid

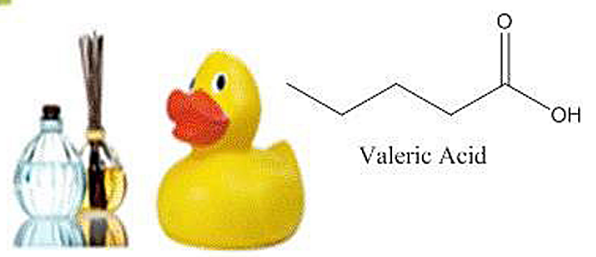

Fragrances Plasticizers

Figure 1. Levulinic acid derivatives and their applications. ${ }^{[18,19]}$
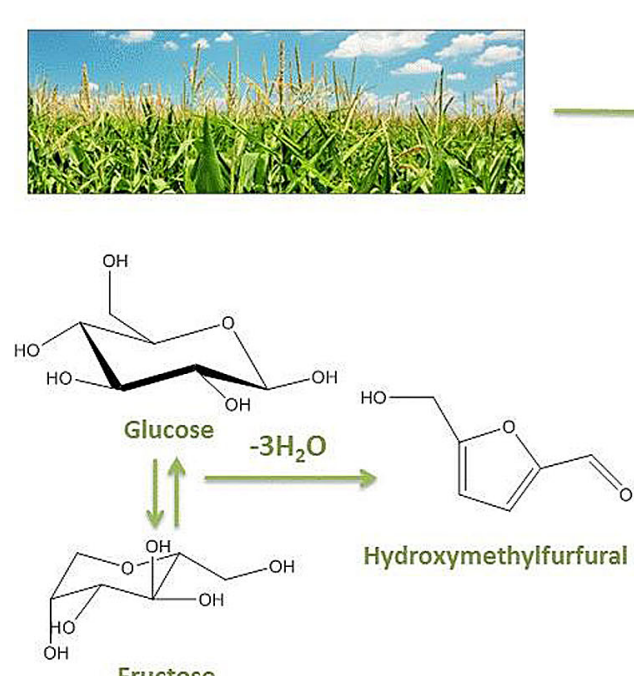

Fructose

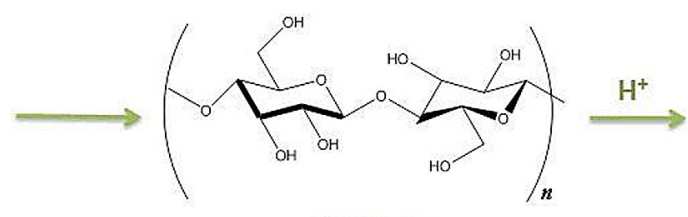

Cellulose

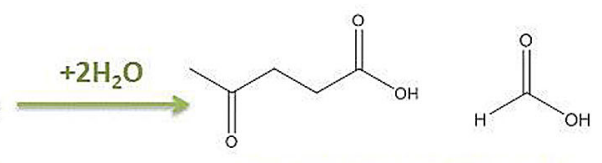

Levulinic Acid + Formic Acid

Figure 2. Formation of levulinic acid from lignocellulosic biomass.

sion of $C_{5}$ sugars from hemicellulose into furfuryl alcohol and further hydrolysis to levulinic acid. Low furfuryl alcohol concentrations are maintained in monophasic systems to decrease the formation of the polymerization and degradation products (humins). ${ }^{[37]}$
The production of LA is generally performed in batch or continuous mode; however, the highest yield is obtained in continuous flow reactors rather than in batch mode. ${ }^{[42]} \mathrm{A}$ significant challenge is the recovery and purification of levulinic acid, which depends on the mode and technology used for its 


\begin{tabular}{|c|c|c|c|c|}
\hline Biomass precursor & Acid concentration & $\begin{array}{l}T \\
{\left[{ }^{\circ} \mathrm{C}\right]}\end{array}$ & $\begin{array}{l}\text { Yield } \\
\text { [\%] }\end{array}$ & Ref. \\
\hline fructose & $3.6-7.2 \% \mathrm{HCl}$ & 95 & 81 & [22] \\
\hline glucose & $5 \% \mathrm{H}_{2} \mathrm{SO}_{4}$ & 170 & 80.7 & [27] \\
\hline starch & $6 \% \mathrm{H}_{2} \mathrm{SO}_{4}$ & 200 & 66.4 & {$[22,28]$} \\
\hline paper & $5 \% \mathrm{H}_{2} \mathrm{SO}_{4}$ & 240 & 59.8 & {$[28]$} \\
\hline pulp residues & $1-5 \% \mathrm{H}_{2} \mathrm{SO}_{4}$ & $210-230$ & $70-80$ & [30] \\
\hline wheat straw & $3.5 \% \mathrm{H}_{2} \mathrm{SO}_{4}$ & 200 & 68.8 & [30] \\
\hline sorghum grain & $8 \% \mathrm{H}_{2} \mathrm{SO}_{4}$ & 200 & 45.6 & [30] \\
\hline glucose & $\mathrm{MeSO}_{3} \mathrm{H}$ & 180 & 41 & [30] \\
\hline fructose & $4-\mathrm{MeC}_{6} \mathrm{H}_{4} \mathrm{SO}_{3} \mathrm{H}$ & 240 & 33.7 & [31] \\
\hline
\end{tabular}

Table 2. Heterogeneous acid catalyzed production of levulinic acid.

\begin{tabular}{|c|c|c|c|c|}
\hline Biomass precursor & Catalyst & $T\left[{ }^{\circ} \mathrm{C}\right] / t[\mathrm{~h}]$ & Yield [\%] & Ref. \\
\hline \multirow[t]{2}{*}{ fructose } & Amberlite IR-120 & $25 / 27$ & 23.5 & [30] \\
\hline & LZY-Zeolite & $140 / 15$ & 43.2 & \\
\hline \multirow[t]{3}{*}{ glucose } & Amberlite IR-120 & $25 / 124$ & 5.8 & [31] \\
\hline & clay catalyst & $150 / 24$ & 12 & \\
\hline & HY-zeolite & $150 / 24$ & 6 & \\
\hline \multirow[t]{2}{*}{ sucrose } & Amberlite IR-120 & $25 / 41$ & 15.6 & [32] \\
\hline & Resin-Dowex & $100 / 24$ & 24 & \\
\hline cellulose & Nafion SAC-13 & $190 / 24$ & 9 & [33] \\
\hline HMF & ZSM-5 & $116 / 2$ & 70 & [33] \\
\hline corn stover & Amberlyst 70 & $160 / 16$ & 54 & [38] \\
\hline cellulose & & & 49 & \\
\hline glucose & $\begin{array}{l}\text { sulfonated graphene } \\
\text { oxide }\left(\mathrm{GO}-\mathrm{SO}_{3} \mathrm{H}\right)\end{array}$ & $200 / 2$ & 50 & [39] \\
\hline cellulose & $\begin{array}{l}\text { sulfonated chloromethyl } \\
\text { polystyrene resin }\end{array}$ & $170 / 10$ & 24 & [40] \\
\hline cellulose & metal chlorides & $180 / 2$ & & [30] \\
\hline rice straw & $\begin{array}{l}\mathrm{CrCl}_{3} \text { and } \mathrm{AlCl}_{3} \\
\text { solid acid } \mathrm{S}_{2} \mathrm{O}_{8} \\
\text { 2-/ } / \mathrm{ZrO}_{2}-\mathrm{SiO}_{2}-\mathrm{Sm}_{2} \mathrm{O}_{3}\end{array}$ & 200/0.17 & 58 & [41] \\
\hline
\end{tabular}

production. The various recovery methods and their advantages and limitations are reported in Table 3.

In the continuous mode of the Biofine process, ${ }^{[49]}$ humins are removed by filtration, followed by atmospheric/vacuum distillation and steam stripping for the separation of LA, which can be obtained in a final purity of approximately 95$97 \%{ }^{[43,50]}$ Solvent extraction has also been applied for the purification and isolation of LA. Solvents such as butyl alcohol, methylene chloride, and diethyl ether have been utilized. Vola- tility, toxicity, and extraction of colored compounds with LA leads to the utilization of furfural as an extraction solvent for LA recovery. ${ }^{[44,45]}$ Membrane separation and adsorption can also be employed to recover and purify LA. Raghavan et al. ${ }^{[29]}$ mention the high boiling point of LA as an inhibitory factor of its recovery by distillation, as large quantities of solvent need to be evaporated, which makes the process energy intensive. Further research has been conducted for the production of greener extraction solvents and to minimize the costs of these processes. In the case of batch-mode processes, extraction of levulinic acid can also be applied in the presence of furfural as an extraction solvent. ${ }^{[44]}$ After the extraction step, levulinic acid is separated from furfural by distillation of furfural.

Levulinic acid has been produced since 1870. Over the years, its basic chemistry and properties have been studied extensively. As levulinic acid has significant potential as an industrial precursor for value-added chemicals and fuels from biomass, over the last decades there has been increasing interest to scale up its production and to use it at both the research and industrial levels for commercial applications. On the research scale, the University of Limerick is a pioneer and the main coordinator of two scientific projects, the Biofine process and the DIBANET project, which mainly focus on the production of ethyl levulinates from organic wastes and residues (DIBANET) and the optimization of LA production and its products $[\delta$-aminolevulinic acid (DALA) and methyltetrahydrofuran (MTHF)] through the Biofine process. DIBANET stands for the Development of Integrated Biomass Approaches NETwork, which promotes the collaboration of six universities from the European Union and seven universities from Latin America. The total budget for the project is $€ 3.7$ million. ${ }^{[49]}$ The Biofine process involves the use of dilute sulfuric acid as a catalyst to initiate multiple acid-catalyzed reactions of $C_{6}$ and $C_{5}$ monosaccharides to give the platform chemicals levulinic acid and furfural as final products. ${ }^{[49]}$ The maximum yield of LA obtained from cellulose through the Biofine process is $50 \%$, and $20 \%$ is converted into formic acid and $30 \%$ into tars. The main advantage of the Biofine process is that it does not rely on the use of any form of microorganism, as is the case in enzymatic hydrolysis and in conventional dilute/concentrated acid hydrolysis technologies. The use of biological agents is often responsible for poor yields and a lower range of feasible feedstocks.

On the industrial scale, levulinic acid is available on the market but in insufficient quantities and is produced by a pro-

Table 3. Advantages and limitations of different recovery processes for levulinic acid (reproduced from review). ${ }^{[8]}$

\begin{tabular}{|c|c|c|c|}
\hline Recovery process & Advantages & Limitations & Ref. \\
\hline vacuum distillation & simple, easy, and well-established technology & extensive energy requirement, formation of byproducts & [43] \\
\hline solvent extraction & no additional processing step required & $\begin{array}{l}\text { large volume of solvent is required, thereby increasing } \\
\text { the cost; toxicity of solvents, extraction of colored compounds }\end{array}$ & {$[44,45]$} \\
\hline steam stripping & high purity product is obtained & energy requirement is extensive & {$[31,43]$} \\
\hline membrane separation & $\begin{array}{l}\text { single-step separation; continuous separation } \\
\text { of products, which leads to enhanced productivity; } \\
\text { minimizes undesired byproduct formation }\end{array}$ & costly, membrane fouling & [46] \\
\hline adsorption & simple & low absorbent capacity limits use at industrial level & [31] \\
\hline ionic liquids & still in research phase & expensive; difficulty in purification & [47] \\
\hline
\end{tabular}


cess that has trouble meeting environmental standards. GF Biochemicals is a company, founded in 2008, that operates a $2 \mathrm{kt}$ per year production facility in Caserta, Italy, and intends to scale up to $8 \mathrm{kt}$ per year by 2017. Eridania Sadam, an Italian agroindustrial group, will invest $€ 1.8$ million in the development of its levulinic acid production technology. Segetis announced in 2013 the successful start-up of their pilot plant facility in Golden Valley, Minnesota, and has demonstrated the viability of its proprietary process to convert biomass into levulinic acid. Avantium is a leading technology company specializing in the area of advanced catalytic research, and it has developed a novel process for the creation of commercial polyethylene furanopate (PEF), a novel $100 \%$ biobased polyester with enhanced barrier, thermal, and mechanical properties over existing packaging materials. ${ }^{[18]}$ Avanitum's YXY process for the production of PEF also produces methyl levulinate as a byproduct (Figure 2), a potential precursor of various biobased feedstocks and applications. (DALA for agrochemicals, diphenolic acid as a polycarbonates monomer, valeric acid for fragrances and plasticizers.)

Levulinic acid is a biomass-derived platform chemical that could play a central role in emerging industries as an intermediate that facilitates the production of biobased commodities. Levulinic acid can be extensively produced from raw lignocellulosic biomass and mono- and polysaccharides such as cellulose and glucose in the presence of liquid mineral acids and heterogeneous solid catalysts. The problems with mineral acids, that is, environmental pollution and equipment corrosion, have led to their replacement by more environmentally beneficial solid catalysts. Further research should be conducted to improve the final yield of LA in the presence of solid heterogeneous catalysts relative to the yield obtained by homogeneous processes. The recent increase in the amount of literature data regarding the production and applications of levulinic acid confirms its potential capability to serve as a biobased chemical intermediate to produce fuels through conventional petrochemical technology. In this review, significant focus will be given on some commercial applications of LA and its pro- duction on an industrial scale, whereas extensive information will be given regarding its potential products such $\gamma$-valerolactone, levulinate esters, aminolevulinic acid, and valeric biofuels. We will first focus on chemicals produced from levulinic acid, such levulinate esters, the different catalytic methods for their production, succinic acid, aminolevulinic acid, and diphenolic acid, whereas later on the review with focus on $\gamma$-valerolactone, a LA-based product, and the different catalytic routes for the conversion of $\gamma$-valerolactone into valuable chemicals such as valeric esters, 5-nonanone, 2-methyltetrahydrofuran, and $\alpha$ methylene- $\gamma$-valerolactone.

\section{Levulinic Acid Derivatives and Their Poten- tial Applications}

\subsection{Levulinate esters}

Esterification can be defined as the transformation of carboxylic acids or their derivatives into esters in the presence of an alcohol. The synthesis of ester compounds by the reaction of carboxylic acids with alcohols is a reversible reaction with water as a byproduct. Starting materials to produce alkyl levulinates are mainly raw biomass or biomass derivatives. Levulinate esters can be mainly produced from levulinic acid through esterification with an alcohol. As levulinic acid is derived from the carbohydrates fraction of biomass, researchers have studied the direct synthesis of alkyl levulinates from carbohydrates or even raw biomass in the presence of various homogeneous, heterogeneous, and enzymatic catalysts.

Levulinate esters have potential applications in the flavoring and fragrance industries and as additives for diesel and biodiesel fuels. ${ }^{[51-54]}$ Several technoeconomic studies have been conducted regarding the use of levulinate esters as fuel additives and for further production of liquid hydrocarbon fuels. ${ }^{[55-59]} \mathrm{A}$ possible pathway for the formation of alkyl levulinates from various biomass precursors is shown in Figure 3.

The most applied method for the reaction of carboxylic acids with alcohols for their conversion into esters is per-

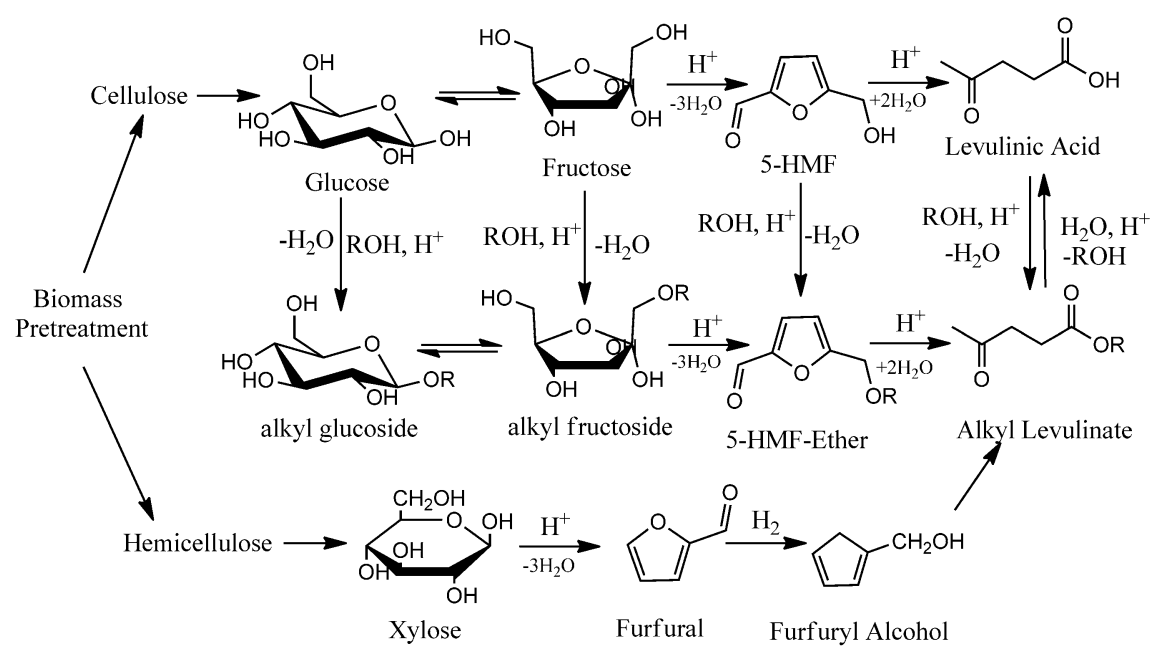

Figure 3. Different possible pathways for the formation of alkyl levulinates from biomass. ${ }^{[60]}$ 
formed in the presence of a homogeneous mineral acid or a heterogeneous catalyst. Uncatalyzed reactions have also been reported as a possible way to produce esters, but the reaction is very slow, as it is a self-catalytic process involving the carboxylic acid itself. ${ }^{[61]}$ Bankole has reported the uncatalyzed esterification of various acids including levulinic acid to ethyl levulinate (levulinic acid/ethanol 1:1) at temperatures of 25 to $250^{\circ} \mathrm{C}$. The highest conversion is achieved at $250^{\circ} \mathrm{C}$ after $60 \mathrm{~min}$ (60\% levulinic acid conversion). ${ }^{[61]}$

\subsubsection{Homogeneous esterification}

The most commonly used mineral acids for the homogeneous esterification of carboxylic acids include sulfuric acid, hydrochloric acid, phosphoric acid, $p$-toluenesulfonic acid, and a mixture of these acids. The liquid-phase reaction is generally a fast and cheap option as a result of the wide availability of acid catalysts and the fact that it is not energy intensive, as it can be performed under temperatures milder than those required for heterogeneous esterification. ${ }^{[61,62]}$ Although the homogeneous esterification of acids has been reported to give better conversions than heterogeneous esterification, it is well known that the use of mineral acids has some significant disadvantages associated with handling, equipment corrosion owing to their miscibility with the reaction medium, separation problems, and disposal and regeneration owing to their toxic and corrosive nature. ${ }^{[61]}$ The liquid-phase esterification of acids in the presence of a suitable acid catalyst has been studied by various groups. Bart et al. have studied the kinetics of levulinic acid esterification with butanol in the presence of sulfuric acid. ${ }^{[63]}$ Yields of $46 \%$ methyl levulinate, $44 \%$ ethyl levulinate, and $37 \%$ propyl levulinate have been reported by Garves in the degradation of cellulose. ${ }^{[64]}$ Pileidis et al. ${ }^{[65]}$ have studied the efficiency of $\mathrm{H}_{2} \mathrm{SO}_{4}$ relative to that of sulfonated carbons and the effect of time and ethanol/acid ratio in the production of ethyl levulinate. Wang et al. ${ }^{[66]}$ have studied the direct synthesis of levulinate esters in the presence of mineral acids (e.g., $\mathrm{H}_{2} \mathrm{SO}_{4}$ and $\mathrm{H}_{3} \mathrm{PO}_{4}$ ) and acid mixtures \{e.g., 2-napthalenesulfonic acid as Brønsted acid and indium(III) trifluoromethanesulfonate $\left[\ln (\mathrm{OTf})_{3}\right]$ as Lewis acid\} in the two-step degradation of cellulose involving alcoholysis of cellulose and formation of glucosides in the first step catalyzed by the Brønsted acid and further conversion into levulinate esters catalyzed by the Lewis acid. As noted above, a high concentration of $\mathrm{H}_{2} \mathrm{SO}_{4}$ can cause equipment corrosion, and serious drawbacks in separation and recycling might be encountered. Several researchers have suggested the use of extremely low acid (ELA), thus an acid concentration less than $0.01 \mathrm{molL}^{-1}$. Several studies have shown the advantages of ELA in the production of glucose ${ }^{[67]}$ and levulinic acid $^{[68]}$ from biomass. Zhu et al. have studied the direct production of ethyl levulinate through glucose ethanolysis in the presence of ELA. ${ }^{[69]}$ They have studied the effect of different acid concentrations in the formation of ethyl levulinate through acid-catalyzed hydration of glucose into ethyl glucoside with ethoxymethylfurfural as the reaction medium followed by further alcoholysis of ethoxymethylfurfural with ethanol to obtain a maximum yield of ethyl levulinate of approxi- mately $40-45 \%$ at $200{ }^{\circ} \mathrm{C}$ after $120 \mathrm{~min} \cdot{ }^{[69]}$ Peng et al. ${ }^{[70]}$ have also presented the efficiency of ELA in the methanolysis of glucose and the synthesis of methyl levulinate. The highest yield of methyl levulinate in this case is $45 \%$ at $200^{\circ} \mathrm{C}$ after $120 \mathrm{~min}$ (ELA concentration $0.01 \mathrm{molL}^{-1}$ ). ELA has also been used to synthesize methyl levulinate directly from cellulose. ${ }^{[71]}$ At the highest ELA concentration $\left(0.01 \mathrm{molL}^{-1}\right)$ at $210^{\circ} \mathrm{C}$, the maximum yield obtained is $50 \%$ after $150 \mathrm{~min}$. Under the same experimental conditions, methyl glucosides have been reported as reaction media. The maximum yields are $28 \%$ at $180^{\circ} \mathrm{C}$ and $6 \%$ at $210^{\circ} \mathrm{C}$ after $180 \mathrm{~min}^{[71]}$

Furfuryl alcohol is another possible precursor for the synthesis of alkyl levulinates. Furfuryl alcohol has been reported for the production of butyl levulinate at extremely low sulfuric acid concentrations in the presence of butanol as the medium. ${ }^{[72]}$ The production of alkyl levulinates directly from pentoses involves a dehydration reaction that produces furfural, followed by hydrogenation to form furfuryl alcohol, which is then converted into alkyl levulinates. ${ }^{[73]}$ At extremely low sulfuric acid concentrations, furfuryl alcohol is converted into butyl levulinate and the maximum yield (80\%) is observed after $8 \mathrm{~h}$ of reaction at $120^{\circ} \mathrm{C}$. In this study, 2-(butoxymethyl)furan is the key intermediate during the conversion of furfuryl alcohol into butyl levulinate. ${ }^{[72,74]}$ Several studies have also been conducted for the synthesis of alkyl levulinates in the presence of liquid-soluble catalysts from various types of biomass and mono- and polysaccharides. ${ }^{[75-80]}$ The formation of different alkyl levulinates from lignocelluloses or starches was first reported by Garves. ${ }^{[75]}$ Bianchi and Romano ${ }^{[76]}$ report the use of naphthalenesulfonic acid for the direct conversion of coniferous wood biomass into alkyl levulinates. Le Van Mao et al. ${ }^{[77,78]}$ state that the amounts of produced esters depend on the carboxylic acid intermediates. To improve the amounts of acid intermediates, they have treated biomass (i.e., pine wood, paper pulp) in ethanol in the presence of sulfuric acid and the Fenton reagent, $\mathrm{Fe}\left(\mathrm{SO}_{4}\right)$ and $\mathrm{H}_{2} \mathrm{O}_{2}$, to achieve a final yield of ethyl levulinate of $20 \%$. Under acidic conditions, in the presence of various alcohols, furfuryl alcohol has also been converted into alkyl levulinates (methyl levulinate: $52 \%$ yield, decyl levulinate: $98 \%$ yield). ${ }^{[81]}$ Peng et al. ${ }^{[72]}$ report the use of a low sulfuric acid (ELA) concentration as a catalytic system for the conversion of biomass-derived furfuryl alcohol into butyl levulinate. ${ }^{[72]}$

High yields of butyl levulinate $(60 \%)$ have also been achieved by the direct solvolysis of cellulose. ${ }^{[7]}$ Various types of biomass such as paper pulp (cellulose $78 \mathrm{wt} \%$ ) and grass (cellulose $35 \mathrm{wt} \%$ ) containing different amounts of cellulose have also been efficiently converted into ethyl levulinate in the presence of liquid catalysts. ${ }^{[80]}$

Various catalytic processes for the synthesis of alkyl levulinates in the presence of homogeneous catalysts are reported in Table 4.

\subsubsection{Heterogeneous esterification}

Heterogeneous catalysts are now the preferred choice to obtain high yields of levulinic acid esters. The advantage of 


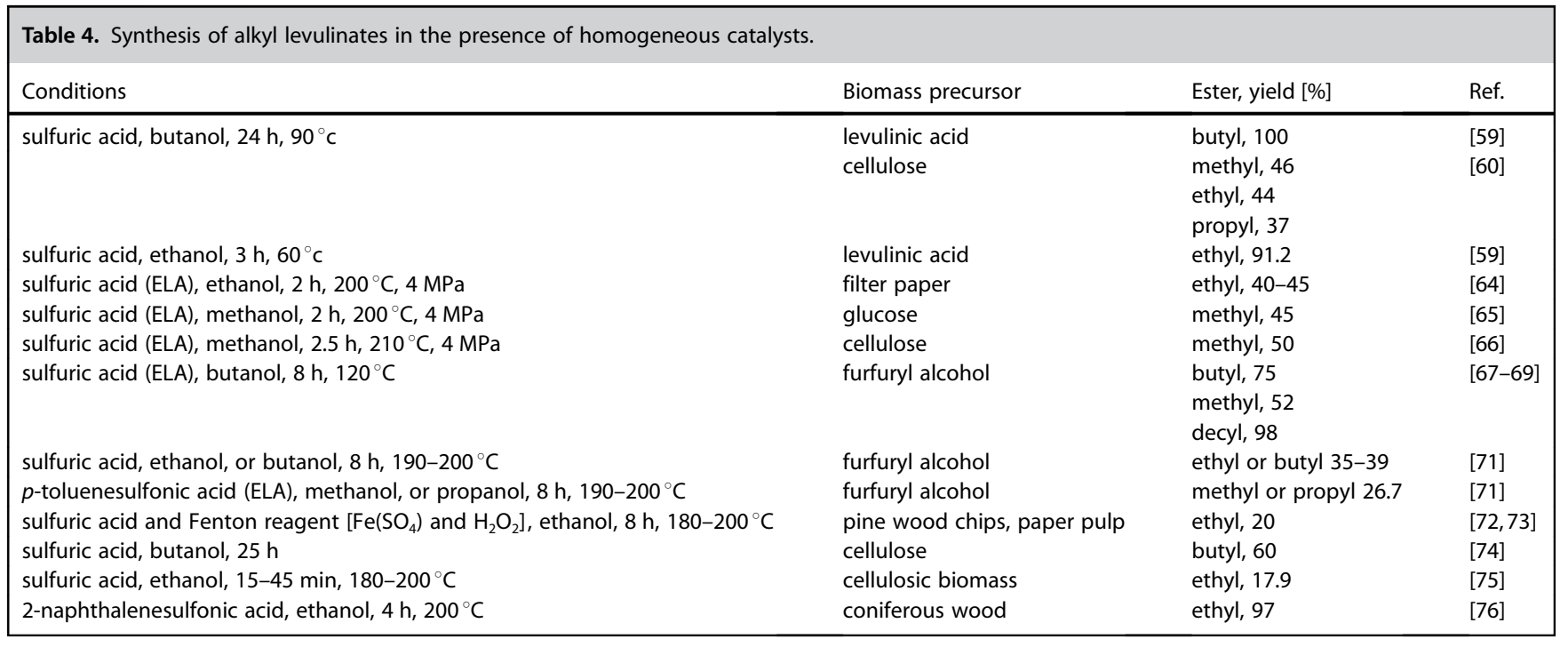

heterogeneous catalysts is that they can easily be separated from the reaction mixture for recyclability and reuse. The use of heterogeneous catalysts limits equipment corrosion compared to liquid acids.

Among various heterogeneous catalysts, HPAs are on the most preferred category of solid catalysts. Owing to their strong Brønsted acidity, HPAs show excellent catalytic activity in various acid-catalyzed reactions. Amongst all HPAs, dodecatungstophosphoric acid (DTPA) is the most stable, and it has the highest Brønsted acidity and thermal stability up to 250$300^{\circ} \mathrm{C} .^{[22,83]}$ The disadvantages of HPAs are their limited specific surface areas and high solubilities in polar media. To overcome these problems and to stabilize their activity, HPAs are often dispersed in porous supports, such as zeolites, SBA-15, activated carbon, and metal oxides. ${ }^{[84-88]}$ Lawson and Salzberg ${ }^{[81]}$ report the use of the montmorillonite K10 HPA for the effective esterification of levulinic acid into butyl levulinate (ester yield of $97 \%$ after $4 \mathrm{~h}$ at $120^{\circ} \mathrm{C}$ ). Nandiwale et al. ${ }^{[84,85]}$ also report the use of desilicated H-ZSM-5 as a support on hetepolyacids. Owing to HPA leaching, loss of activity is noticed after three to four runs. In that study, several solid acid catalysts including sulfated zirconia, resin Amberlyst-15, sulfated zirconia, and $\beta$ YZSM-5 have been used. The combination of DTPA on desilicated $\mathrm{H}-\mathrm{ZSM}-5$ results in an efficient robust catalyst that is capable of achieving a conversion of levulinic acid of $94 \%$ with $100 \%$ ethyl levulinate selectivity. The solid catalyst is stable over four cycles. ${ }^{[81]}$ Yan et al. ${ }^{[86]}$ also report the synthesis of mesoporous silica supported Keggin $\left(\mathrm{H}_{4} \mathrm{SiW}_{12} \mathrm{O}_{40}-\mathrm{SiO}_{2}\right)$ heteropolyacid for the esterification of levulinic acid in methanol and ethanol media. The highest yield/selectivity for ethyl levulinate is $75 / 67 \%$ and for methyl levulinate is $79 / 73 \% .{ }^{[84]}$ Silica-supported Wells-Dawson heteropolyacid is a selective catalyst for the production of ethyl levulinate $\left(70 \%\right.$ yield at $78^{\circ} \mathrm{C}$ after $10 \mathrm{~h})^{[87]}$

Zeolites are crystalline, microporous, highly ordered aluminosilicates with intracrystalline pore structures of molecular dimensions. ${ }^{[89]}$ Its unique acid properties, its high surface area, and its large pore dimensions make $\mathrm{H}-\beta$ (H-BEA) zeolite a very promising catalyst for acid-catalyzed reactions. ${ }^{[0,91]}$ Patil et al. ${ }^{[90]}$ and Maheria et al. ${ }^{[91]}$ report the use of H-BEA zeolite for the efficient conversions of ethyl levulinate and butyl levulinate, respectively. In these studies, the high surface area (600$700 \mathrm{~m}^{2} \mathrm{~g}^{-1}$ ) and the stability of the catalyst after four to five catalytic runs is also reported. ${ }^{[90,91]}$

During the last years, sulfonated materials have also been studied as efficient catalysts for esterification reactions. ${ }^{[2-97]}$ The esterification of levulinic acid in the presence of various alcohols by using sulfonic mesostructured silicas has been studied by Melero et al. ${ }^{[92]}$ The materials show remarkable yields of ethyl levulinate owing to their strong acidity provided by the $\mathrm{SO}_{3} \mathrm{H}$ and $\mathrm{SO}_{4}{ }^{2-}$ functional groups. ${ }^{[86]}$ Sulfonic materials undergo significant leaching, which has also been reported in other studies. ${ }^{[65,91,93]}$ Teixeira da Silva et al. ${ }^{[93]}$ have achieved $55 \%$ yield of ethyl levulinate by using sulfonated carbon nanotubes. Several studies have been conducted with sulfated oxides. ${ }^{[94-97]}$ Teixeira da Silva et al. ${ }^{[94]}$ and Leahy et al. ${ }^{[95]}$ report highly acidic $\mathrm{SO}_{4} / \mathrm{SnO}_{2}$ and $\mathrm{SO}_{4} / \mathrm{TiO}_{2}$ for the efficient conversion of levulinic acid into ethyl levulinate.

Sulfonated carbonaceous materials have been synthesized and investigated as environmentally benign, cheap, and recyclable catalysts for esterification processes. Budarin et al. ${ }^{[97]}$ have synthesized a sulfonated Starbon 400 with a $\mathrm{SO}_{3} \mathrm{H}$ loading of $0.5 \mathrm{mmol} \mathrm{g}^{-1}$. Pileidis et al. ${ }^{[65]}$ have synthesized sulfonated hydrothermal carbons from various biomass precursors as solid acid catalysts for the esterification of levulinic acid into ethyl levulinate. Roldan et al. ${ }^{[98]}$ have optimized esterification catalysts obtained by hydrothermal carbonization of glucose for the production of glycerol esters. The highest selectivity of the sulfonated catalysts is obtained at mid-reaction temperatures of $90-110^{\circ} \mathrm{C}$ and is $57 \%$ for triacylglycerides, whereas the selectivity of diacylglycerides is approximately $38 \%{ }^{[98]}$ ValleVigón, Sevilla, and Fuertes ${ }^{[99]}$ have synthesized highly functionalized porous silica-carbon composites made up of sulfonic groups attached to a carbon layer coating the pores of three types of mesostructured silica. The high density of the sulfonic groups in combination with the mesoporous structure of the 
composites ensures that a large number of active sites are easily accessible to the reactants.

Glucose, the monomer of cellulose, is the most abundant monosaccharide, and extensive research has been conducted on the conversion of glucose into valuable levulinate esters. Fructose, which is also obtained by glucose isomerization, has also been intensively used for the production of alkyl levulinates. Most research efforts mainly focus on the production and optimization of solid acids for the direct transformation of saccharides into alkyl levulinates. Despite their low thermal stability, Amberlyst resins have extensively been used in the case of fructose. ${ }^{[100,101]}$ Saravanamurugan, Nguyen Van Buu, and Riisager report the use of acidic ionic liquids ${ }^{[102]}$ and sulfonic acid functionalized SBA-15 catalysts and zeolites ${ }^{[103,104]}$ in the production of alkyl levulinates from different carbohydrates in the presence of ethanol. In the case of ionic liquids, fructose gives significant yields at $140{ }^{\circ} \mathrm{C}(74 \%)$, whereas the glucose reaction stops at the alkyl glycoside stage. After separation, the ionic liquids are reusable. In the presence of zeolites, the conversion of fructose mainly stops in the HMF ether, whereas the ester yield is low $(\approx 10 \%)$. Sulfonated SBA-15 materials give good yields of ethyl levulinate from glucose $(\approx 50 \%){ }^{[103]}$ In the case of glucose, ethyl glycoside is mainly formed, except from sulfated zirconia, which gives an efficient quantity of ethyl levulinate owing to its Lewis acid sites that can promote glucose isomerization to fructose. Recently, Wilson et al. ${ }^{[105]}$ have reported the use of sulfated zirconia for the one-pot synthesis of ethyl levulinate from glucose. The yield of ethyl levulinate is dependent on the reaction temperature, and the highest yield is obtained at $140-150^{\circ} \mathrm{C}$. The appearance of polymer degradation products (i.e., humins) is reported at higher temperatures. ${ }^{[105]}$ The use of zeolites and mesoporous $\left(\mathrm{SO}_{3} \mathrm{H}\right)$ functionalized carbon/silica composites for the efficient conversion of glucose $^{[105]}$ and fructose ${ }^{[106]}$ into ethyl levulinate has also been studied by Wilson and Valente, respectively.

For pure biomass and polysaccharides, several studies have been conducted with solid acids. The efficiency of sulfated zirconia, sulfonated carbons, sulfonated resins, and heteropolyacids has been studied for the treatment of cellulose in the presence of ethanol and methanol at $180^{\circ} \mathrm{C}^{[107]}$ Deng et al. ${ }^{[107]}$ have achieved the use of alkyl glycosides as main reaction products, whereas alkyl levulinates are only obtained as byproducts. Sulfonated carbons obtained from biochar have been reported as solid catalysts and provide a $30 \%$ yield of methyl levulinate. The recyclability and reusability after five catalytic cycles is also mentioned. ${ }^{[108]}$ Carbon and carbon-silica catalysts containing $\mathrm{SO}_{3} \mathrm{H}$ groups (chemical activation with $p$ toluenesulfonic acid) have also been studied by Valente et al. ${ }^{[109]}$ The effect of reaction time and the acid/organic precursor ratio are also mentioned in this study, and the highest yield of ethyl levulinate $(70 \%)$ is achieved after a reaction time of $4 \mathrm{~h}$. Heteropolyacids have also been reported as efficient catalysts for alkyl levulinates directly from cellulose. Rataboul ${ }^{[110]}$ reports the production of methyl levulinate in supercritical methanol/water with yields close to $20 \%$. The Tominaga group reports the direct production of methyl levulinate in the presence of Lewis/Brønsted acid mixtures. ${ }^{[111]}$ In the absence of a Lewis acid, sugars are mainly reported as products, whereas the yield of methyl levulinate is $20 \%$. The highest yields of ethyl levulinate $(70 \%)$ are obtained in the presence of acid mixtures. The effectiveness, reusability, and robustness of $\mathrm{Al}_{2}\left(\mathrm{SO}_{4}\right)_{3}$ after five cycles has been reported by $\mathrm{Xu}$ et al. ${ }^{[112]}$ The highest yield of alkyl levulinate (44\%) from cellulose is achieved after $300 \mathrm{~min}$ at $180^{\circ} \mathrm{C}$. The synthesis and properties of sulfonated $\mathrm{TiO}_{2}$ have also been studied by Kuo et al. ${ }^{[101]}$

The first reports of the use of furfuryl alcohol as a non-cellulose-derived reactant for the production of alkyl levulinates are mainly found in the patent literature. ${ }^{[113,114]}$ The efficiency of resins and zeolites for the ethanolysis of furfuryl alcohol has been studied by Van de Graaf. The authors of these studies mainly describe that the accessibility of furfuryl alcohol to the acid sites plays a more crucial role during the reaction than the acid strength. This is the main reason why gel-type resins promote the formation of diethyl ether, as ethanol has better accessibility to the acid sites than less-polar furfuryl alcohol. ${ }^{[17,115]}$ The relationship between the texture of the zeolites or Amberlyst resins and the formation of ethyl levulinate has also been studied by Neves et al. ${ }^{[116]}$ The main conclusion is that a synergy between porosity, acid site strength, and density is necessary, but the main parameter for the efficient formation of alkyl levulinates is the accessibility of the reactants to the acid sites. González Maldonado et al. ${ }^{[117]}$ have undertaken a theoretical and experimental approach to the formation of ethyl levulinate by furfuryl alcohol by using LC-MS and NMR spectroscopy with high-level quantum-chemical calculations. Finally, in the case of furfuryl alcohol, several studies have been conducted for the use of $\mathrm{SO}_{3} \mathrm{H}$-functionalized ionic liquids as efficient acid catalysts with environmental and economic benefits, owing to their recyclability and their flexibility to act as solvent/catalyst systems. ${ }^{[118-121]}$

\subsubsection{Enzymatic esterification}

The use of enzymes in the synthesis of esters has increased extensively in recent years (Table 5). ${ }^{[122-125]}$ Enzymatic synthesis offers several advantages over conventional chemically catalyzed reactions (e.g., mild reaction conditions, low energy requirements, minimal waste disposal, ease of product isolation, and biocatalyst reusability). ${ }^{[122]}$ The enzymatic synthesis of levulinate esters has been studied by Yadav and Borkar. ${ }^{[123]}$ These authors mainly focus on the kinetics and the mechanism of the lipase-catalyzed esterification of levulinic acid with butanol in the presence of tetrabutyl methyl ether as a solvent. Butyl levulinate is obtained in $90 \%$ yield and full selectivity is achieved at low temperatures in the presence of immobilized Novozyme 435 (Candida Antarctica lipase) in a macroporous polyacrylic resin (3 equiv. butyl alcohol, tetrabutyl methyl ether as solvent). ${ }^{[124]}$ The same experiments conducted in the absence of the solvent give a final yield of butyl levulinate of $96 \%$.

\subsubsection{Ionic liquids}

As mentioned above, homogeneous and heterogeneous catalytic systems are quite efficient for the production of levulinate 


\begin{tabular}{|llll|}
\hline \multicolumn{2}{|l|}{ Table 5. Production of alkyl levulinates in the presence of enzymes. } & & \\
\hline Conditions & Biomass precursor & Ester, yield [\%] & Ref. \\
\hline Novozym $435\left(500 \mathrm{mg}, 65^{\circ} \mathrm{C}, 24 \mathrm{~h}\right)$ & glycerol & ethyl, 65 & {$[122]$} \\
Novozym $435\left(35 \mathrm{mg}, 50^{\circ} \mathrm{C}, 2 \mathrm{~h}\right)$ & levulinic acid & ethyl, 80 & {$[123]$} \\
Lipozyme RM IM $\left(35 \mathrm{mg}, 50^{\circ} \mathrm{C}, 2 \mathrm{~h}\right)$ & & ethyl, 40 & ethyl, 30 \\
Lipozyme $\mathrm{TL} I \mathrm{M}\left(35 \mathrm{mg}, 50^{\circ} \mathrm{C}, 2 \mathrm{~h}\right)$ & ethyl, 94 & [124] \\
Novozym $435\left(300 \mathrm{mg}, 55^{\circ} \mathrm{C}, 4 \mathrm{~h}\right)$ & levulinic acid & & \\
\hline
\end{tabular}

esters from various biomass precursors. However, problems associated with these processes, such as extreme corrosiveness and the separation and neutralization of the mineral acids in homogeneous reactions and the deactivation and reusability of heterogeneous catalysts, ${ }^{[62]}$ limit their practical application in esterification reactions. To limit these problems, multiphase systems such as ionic liquids (ILs) have been revealed as green reaction systems with remarkable solubility, thermal stability, and negligible volatility. ${ }^{[120]}$ In the case of esterification reactions, ionic liquids have been extensively studied as catalysts, and high rates of conversion and high selectivity have been reported. The main disadvantages are the high IL content of the reaction media, long reaction times, and the removal of water as a byproduct from the reaction system.

Research on the use of ionic liquids for the synthesis of levulinate esters is quite limited. Imidazolium- and pyridiniumbased ILs functionalized with acidic groups such as $\mathrm{SO}_{3} \mathrm{H}, p$-toluenesulfonic acid (PTSA), and $\mathrm{ClSO}_{3} \mathrm{H}$ have been studied by Saravanamurugan et al.; in the presence of naphthalene as an added solvent, these systems show $70 \%$ selectivity to methyl levulinate with hydroxy methyl furfural ether as a byproduct. ${ }^{[102]}$ Rode et al. report the use of ionic liquids functionalized with acidic anions such as $\mathrm{HSO}_{4}, \mathrm{ClSO}_{3} \mathrm{H}$, PTSA, trifluoroacetic acid (methylimidazolium), $\mathrm{HSO}_{4}$, and trifluoroacetic acid 1-methylpyrrolidin-2-one to catalyze the alcoholysis of furfuryl alcohol in the presence of methanol, ethanol, butanol, and isopropyl alcohol to the corresponding levulinic esters under mild temperature $\left(90-130^{\circ} \mathrm{C}\right)$ conditions. ${ }^{[120]}$

The production process of alkyl levulinates involves the use of ionic liquids and homogeneous and heterogeneous or enzymatic catalytic systems. Both the advantages and disadvantages of these systems have been extensively studied and mentioned above. The depletion of fossil-fuel resources and their negative environmental impact has turned the interest of the scientific community to their replacement with alternative renewable resources. Among the efforts for the conversion of abundant biomass into valuable chemicals and fuels, the production of alkyl levulinates as replacements of petroleumbased products has attracted significant attention. Alkyl levulinates are known for their properties as diesel and biodiesel additives and for widespread applications in the fragrance and flavor industries.

A significant problem that is not often mentioned and that has not been extensively studied by researchers is the isolation and purification of the final alkyl levulinates. This issue should seriously be taken into account, especially on scale-up processes and on the industrial-scale production of alkyl levulinates. Peng et al. ${ }^{[71,72]}$ mention product isolation during the efficient esterification of cellulose and furfuryl alcohol into methyl levulinate and butyl levulinate in the presence of extremely low concentrations of sulfuric acid. Upon completion of the reaction, the resulting product mixture is neutralized and dehydrated with calcium oxide and is then filtered to collect the liquidphase products for isolation. On the basis of boiling temperatures, the liquid-phase components are isolated by a distillation technique combining atmospheric distillation with vacuum distillation. The light fraction (low-boiling substances) is separated first by atmospheric distillation at $80^{\circ} \mathrm{C}$ and contains approximately $96 \%$ alcohol and a very small amount of esters, as determined by GC analysis. This fraction can be reused as the reaction medium without any substantial change in the yield of the levulinate ester. Next, high-boiling products in the residual component are very difficult to distill, even at high temperature by vacuum distillation, probably because they are firmly bound to the solid humins. For this reason, high-boiling paraffin (dodecane) is added to the residual component to help distil the heavy products; it acts as a desorption driving agent for heavy products. At this stage, the component mixture is isolated by vacuum distillation at $145^{\circ} \mathrm{C}$, whereas the heavy fraction is collected. The heavy fraction automatically divides into two layers. The upper layer contains predominantly dodecane (over 99\%), which can be reused to help distil the heavy fraction, and the lower layer contains primarily levulinate ester (over $96 \%$ ), a very small amount of levulinic acid, dodecane, and unknown substances, as detected by GC-MS.

We have extensively reported research conducted on the production and applications of alkyl levulinates. Levulinate esters can be produced in high yields from biomass-derived molecules such as levulinic acid and furfuryl alcohol or by starting from raw lignocellulosic materials. Much effort has been made to use homogeneous mineral acids and heterogeneous solid catalysts. Improvements are necessary owing to limited yields and selectivity issues in the case of solid catalysts. This will be possible by introducing robust, efficient, and selective solid catalysts to minimize the formation of byproducts. Research has also been focused on the use of enzymes and ionic liquids to achieve yields comparable to those obtained with homogeneous catalytic systems by avoiding limitations associated with separation in the case of soluble mineral acids. The recent increase in literature data regarding the production and applications of alkyl levulinates as fuel additives and solvents confirms their potential as biobased compounds that can participate in the development of green-chemistry processes. After extensive research on the conversion of levulinic acid into esters under different catalytic methods (e.g., homogeneous and heterogeneous catalysis and ionic liquids and 
enzymes as catalysts), our interest will be on LA products such as DALA succinic acid and diphenolic acid and their applications as agrochemicals and soil additives, solvents, fuel and food additives, cosmetics, and pharmaceutical products.

\section{2. $\Delta$-Aminolevulinic acid}

$\Delta$-Aminolevulinic acid (DALA, Figure 4) is a natural substance that is present in plants and animals cells. ${ }^{[126-128]}$ DALA is a sustainable, highly selective, environmentally benign herbicide that shows high activity towards dicotyledonous weeds and little activity towards monocotyledonous crops (e.g., corn maize, wheat, and barley). ${ }^{[129]}$ Recently, studies have shown that DALA can be useful as an insecticide and as an active component in photodynamic therapy in cancer treatment. ${ }^{[129,130]}$

The conventional mechanism for the production of DALA from LA involves the selective introduction of an amino group at the $\mathrm{C} 5$ position. The most common approach is the bromination of LA in an alcohol medium to give mixtures of the 5bromo- and 3-bromoesters that can be separated by distillation $^{[131]}$ and then 5 -bromolevulinate is aminated by using nucleophilic nitrogen species. ${ }^{[132]}$ The conventional synthesis of DALA is shown on Figure 5. LA is brominated to give 5-bromolevulinic acid, which is then treated with potassium phthalimide to introduce an amino group. Reaction intermediate $\mathbf{A}$ is then hydrolyzed under acidic conditions to give DALA. The major disadvantages of this process are the low yields of the first two steps and the large amount of waste product B in the final step. The introduction of an amino group is highly inefficient because of the single atom that is used from potassium<smiles>NCC(=O)CCC(=O)O</smiles>

DALA phthalimide. In general, the conventional synthesis of DALA can be performed on laboratory scale, but it is not suitable for the large industrial-scale synthesis of DALA owing to the use of expensive starting materials, toxic intermediates, and the need for multistep processes.

A study by the National Renewable Energy Laboratory (NREL) has been mainly focused on the improvement of the synthesis steps and the overall cost (Figure 6). The work of the NREL has significantly improved the yield of each step $(\approx 80 \%)$ and the purity of DALA $(\approx 90 \%)$. ${ }^{[133]}$

Several studies are still being performed for the efficient production of DALA from LA. The conventional synthesis of DALA, which has major problems and suffers from low product yield, results in the formation of an expensive product that is mainly used for highly selective herbicidal treatments and expensive cancer therapies. Lower-costing Biofine-derived DALA has large potential applications in agricultural and horticultural processes.

\subsection{Succinic acid}

Succinic acid (SA) is a 1,4-dicarboxylic acid and is considered one of the top 12 value-added chemicals produced from biomass. ${ }^{[134]}$ Covering a total market of $\$ 400$ million USD per year, succinic acid is used as a $\mathrm{C}_{4}$ building block for various fine chemicals with potential applications as fuel additives, solvents, food/cosmetics/pharmaceuticals, and polymers. ${ }^{[135-140]} \mathrm{Al}-$ though several studies have been conducted for the transformation of LA into various products, until recently, little attention has been given to its oxidation processes. $\mathrm{V}_{2} \mathrm{O}_{5}$ has been referred to as an efficient oxidation catalyst to convert $L A$ into SA. Dunlop, Smith and Shelbert have patented the oxidation of $\mathrm{LA}$ with $\mathrm{V}_{2} \mathrm{O}_{5}$ at high reaction temperatures $\left(360-400^{\circ} \mathrm{C}\right) . .^{[141]}$ Van Es et al. ${ }^{[142]}$ have also patented the oxidation of LA to SA under mild conditions $\left(40-60^{\circ} \mathrm{C}\right)$ over $1-4 \mathrm{~h}$ in the presence of $\mathrm{V}_{2} \mathrm{O}_{5}$ and nitric acid as the oxidant. Another approach for the oxidation process is the reaction with bromoamides in perchloric acid $\left(\mathrm{HClO}_{4}\right)$ with mercuric acetate $\left[\mathrm{Hg}(\mathrm{OAc})_{2}\right]$, simi-

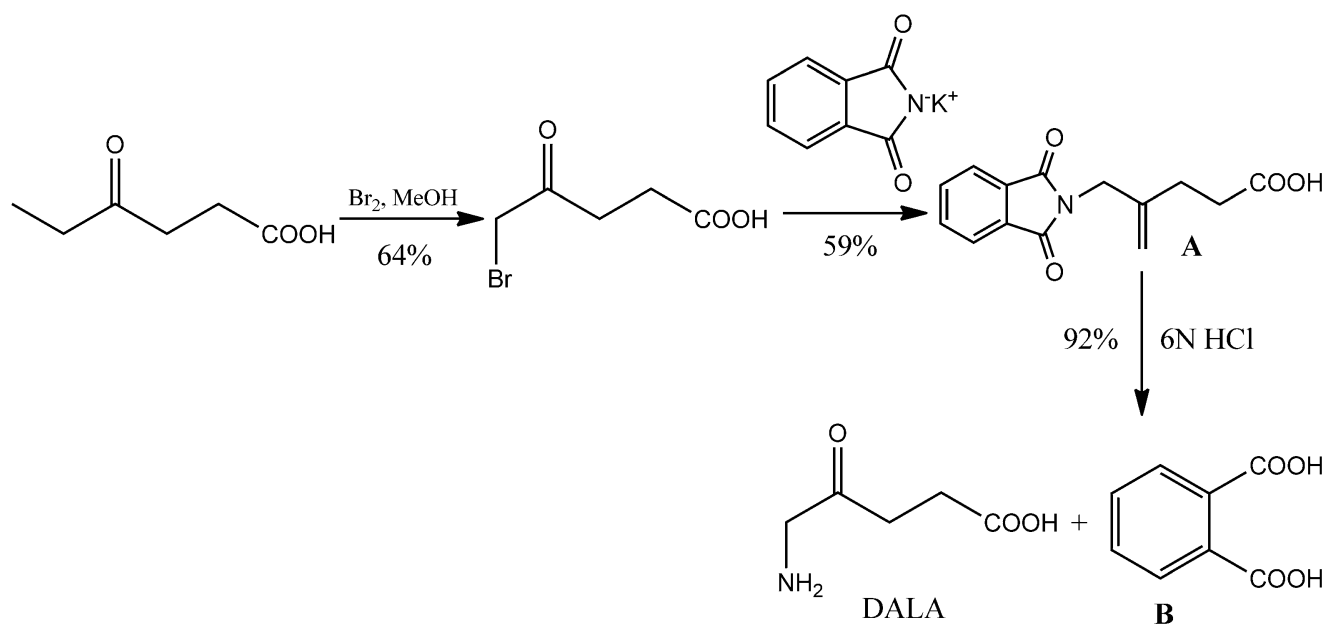

Figure 5. Conventional synthesis of DALA. ${ }^{[132]}$ 


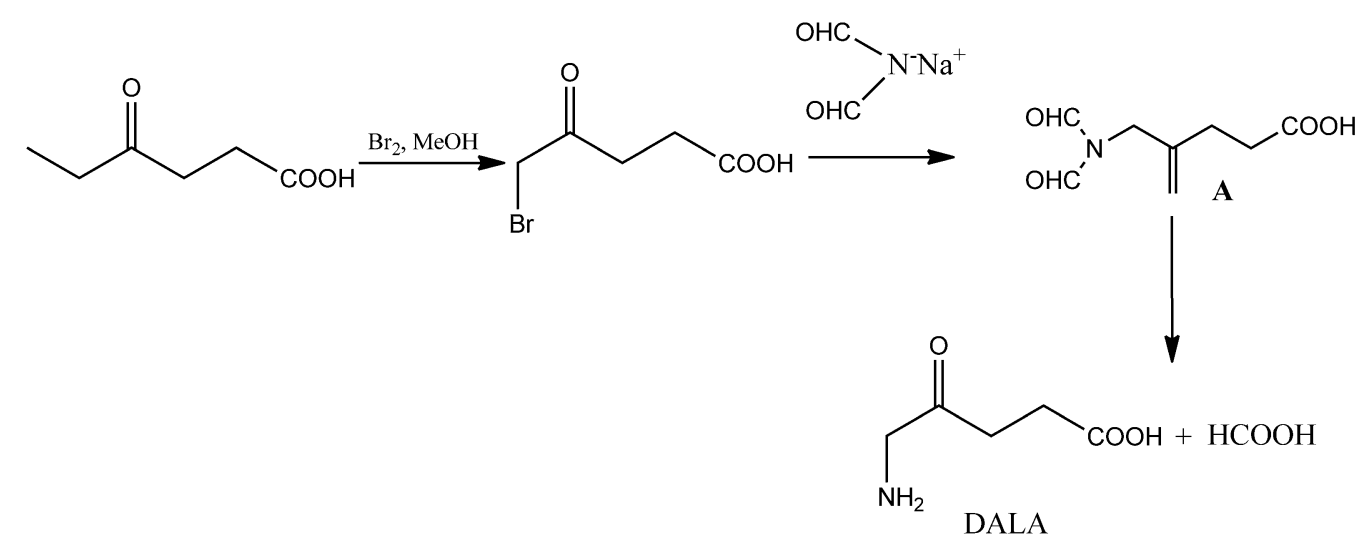

Figure 6. NREL synthesis of DALA. ${ }^{[133]}$

lar to the $\mathrm{V}_{2} \mathrm{O}_{5}$-based transformation, but the toxicity of mercuric salts is a significant issue for environmental concern. Lately, Parvulescu et al. ${ }^{[143]}$ have reported the synthesis of rutheniumbased magnetic nanoparticles as efficient solid catalysts for the conversion of LA into SA. Higher yields are achieved at temperatures of approximately $150-180^{\circ} \mathrm{C}$. The effect and efficiency of different mineral acids during the oxidation of levulinic acid to succinic acid has been studied by Mascal et al. ${ }^{[144]}$ The reaction with $\mathrm{H}_{2} \mathrm{O}_{2}$ in aqueous sulfuric acid gives a mixture of succinic acid (48\%) as the main product with acetic acid, formic acid, methanol, and other byproducts. The isolation of succinic acid is mentioned as the main problem of the process as a result of the process used to recycle sulfuric acid, which significantly increases the energy cost of the reaction. ${ }^{[144]}$

The industrial potential of succinic acid was first recognized by Zeikus. ${ }^{[145]}$ The main applications of succinic acid ${ }^{[146]}$ are in the food market as a pH regulator, antimicrobial agent, and flavoring agent, and in the pharmaceutical industry as an additive for vitamins and for the production of antibiotics and amino acids. ${ }^{[147]}$ Succinic acid is also used as a foaming agent, surfactant, and detergent, and it is also used in the metal industry as an ion chelator preventing metal corrosion and pitting. ${ }^{[146]}$ Succinic acid can be used as a precursor of many important chemicals, including maleic anhydride, 1,4-butanediol, 2-pyrrolidinone, 1-methylpyrrolidin-2-one (NMP), THF, succinate salts, and $\gamma$-butyrolactone (GBL). ${ }^{[148]}$ Maleic anhydride is an important starting material for the manufacture of valuable chemicals such as GBL, 1,4-butanediol, and THF. GBL is mainly used for the production of pyrrolidones, such as NMP and $N$-vinylpyrrolidone. GBL can also be used as a solvent. The annual production of GBL is approximately $250000 \mathrm{t}$ ( $20 \%$ from USA production sites). ${ }^{[135]}$ 2-Pyrrolidone is an intermediate for the production of nylon-4-type polymers and is used in the synthesis of medicines, pharmaceuticals, and agrochemicals. ${ }^{[149]}$ NMP is a useful solvent for polyurethanes, polyacrylonitriles, and heterocyclic polymers with high melting points. ${ }^{[150]}$ Lately, NMP has been used as the solvent of choice for the exfoliation of graphene. ${ }^{[151-153]}$ NMP can also be used as a replacement for chlorinated solvents because of its low volatility in the emissions of volatile organic compounds. 1,4-Butanediol is the pre- cursor for the production of THF and polybutylene terephthalate, which are formed on a large global marketof $1.3 \mathrm{Mt}$ per year. ${ }^{[135]}$ Finally, THF is the monomer for the production of polytetramethylene ether glycol, which is produced widely at a level of $440000 \mathrm{t}$ annually. ${ }^{[135]}$ The main derivatives of succinic acid are shown in Figure 7:

\subsection{Diphenolic acid}

Diphenolic acid (DPA) is produced by the condensation of levulinic acid with two moles of phenol (Figure 8). DPA is a structural analogue of bisphenol A (BPA), and it is used as a direct replacement of BPA in the production of polycarbonates, epoxy resins, polyarylates, and other polymers, especially if phenol can also be produced from the depolymerization of lignin. ${ }^{[154]}$ DPA has numerous applications in lubricants, adhesives, and paints. ${ }^{[155]}$ The lower cost of BPA as a precursor has reduced the market for DPA. The development of DPA as a BPA replacement and the properties of the resulting polymers will provide new sustainable opportunities for the chemical industry. The production of DPA is shown in Figure 8.

Traditional catalysts for the production of DPA include strong Brønsted mineral acids such as $\mathrm{HCl}$ and $\mathrm{H}_{2} \mathrm{SO}_{4}{ }^{[157]} \mathrm{Re}-$ cently, environmental and economic issues have encouraged the design of processes, in which the use of harmful substances and toxic wastes are avoided. Heterogeneous catalysts have significant advantages over mineral acids. Clark et al. ${ }^{[156]}$ suggest the design of mesoporous HPAs for the effective production of DPA from levulinic acid. Bulk HPAs have low surface areas and low efficiencies owing to a limited number of acid sites for catalytic reactions. ${ }^{[156]}$ Silica-supported Keggin catalysts have been produced with a pore size of approximately $0.6 \mathrm{~nm}$ and a BET surface area of $400-800 \mathrm{~m}^{2} \mathrm{~g}^{-1}$. Leaching during the catalytic process has also been reduced. The highest conversion of LA into DPA is $60-80 \%$ (similar to mineral acids). ${ }^{[156]}$ The thiol-promoted synthesis of diphenolic acid in the presence of sulfonated hyperbranched poly(arylene oxindole)s has also been studied by Sels et al. ${ }^{[158]}$ In the presence of thiols as additives, the final yield of DPA is $38-52 \%$ (LA conversion 55$70 \%)$. In the case of Nafion and Amberlyst catalysts, the final 


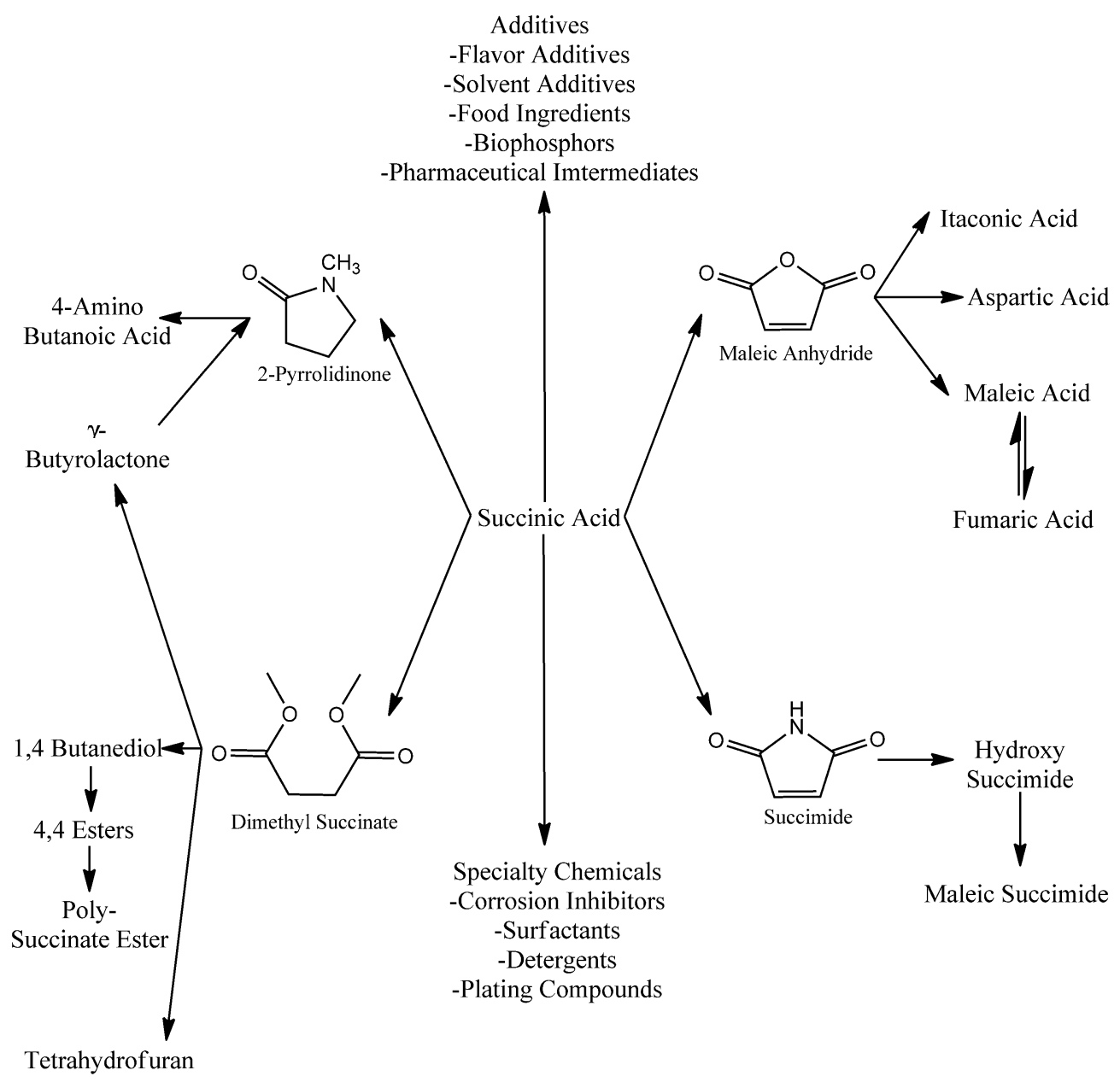

Figure 7. Succinic acid derivatives and their applications. ${ }^{[134]}$<smiles>O=C(O)CCC(=O)Oc1ccccc1</smiles><smiles>CC(CC(=O)O)(CC(=O)O)c1ccc(O)cc1</smiles><smiles>C=CC=C(CO)C(C)(CC(=O)O)c1ccc(O)cc1</smiles>

Figure 8. Condensation of levulinic acid and phenol to diphenolic acid. ${ }^{[156]}$

LA conversion is approximately $35-40 \%$, whereas at the same time the DPA selectivity is decreased to $18-30 \%$. Guo et al. ${ }^{[159]}$ have also suggested the production of Wells-Dawson supported HPAs, but the yields and selectivities of the final DPA product are limited relative to those obtained with other supported heteropolyacids.

The main disadvantage in the production of DPA is the high cost of levulinic acid, which increases the market price of DPA (\$6 per $\mathrm{kg}$ ). The production of LA from biomass at an economically competitive cost could result in a market price of $\$ 2.4$ per $\mathrm{kg}$, which would lead to the progressive substitution of BPA and an increase in the use of renewable biomass-derived DPA.

\subsection{Angelica lactone and hydroxypentanoic acid}

Angelica lactone and hydroxypentanoic acid are mainly referred to the bibliography of intermediates in the production of GVL from LA. There are two different pathways for the formation of these intermediates: the first one involves production of GVL through hydrogenation of levulinic acid with hydroxypentanoic acid as an intermediate, and the second path is the acid-catalyzed dehydration of levulinic acid to angelica lactone and further hydrogenation to GVL. In the case of hydroxypentanoic acid, Wang et al. ${ }^{[160]}$ report the use of secondary alcohols in Meerwein-Ponndorf-Verley reduction. In the 
second case, an acidic medium is used to promote the polymerization of angelica lactone with lower yields of GVL as a consequence. ${ }^{[161]}$ Cao et al..$^{[162]}$ have studied the use of ionic liquids with a $\mathrm{Pd} / \mathrm{C}$ catalyst for the effective conversion of angelica lactone into GVL. The angelica lactone dimer (Figure 9), the intermediate product in the production of GVL, is a novel feedstock for the production of branched $C_{7}-C_{10}$ hydrocarbons as gasoline blends with a high volatility range. ${ }^{[163]}$ In the presence of different catalytic systems, higher yields are achieved for the $C_{10}$ hydrocarbon (i.e., 3-ethyl-4-methylheptane, $\approx 70 \%$ ).

\section{6. $\gamma$-Valerolactone}

In the last part of this review, for which we focus on levulinic acid biorefineries, levulinic acid products, and their potential applications, we will also focus on $\gamma$-valerolactone (GVL). GVL is a five-carbon (valero-) cyclic ester with five atoms (four carbon atoms and one oxygen atom) in the ring ( $\gamma$-lactone). The properties of GVL make it a stable and reactive compound to produce valuable chemicals from biomass such as valeric esters, 5nonanone, 2-methyltetrahydrofuran, and $\alpha$-methylene- $\gamma$-valerolactone. ${ }^{[34,36,164-166]} \mathrm{GVL}$ can be produced from LA through multiple pathways (Figure 10). Starting from LA, hydrogenation leads to the formation of $\gamma$-hydroxyvaleric acid as an unstable intermediate, which undergoes ring closure by intramolecular esterification and loses a water molecule to form GVL. ${ }^{[164]}$ The second pathway starts with the dehydration of LA to form angelica lactone, which is followed by hydrogenation to GVL. ${ }^{[161]}$

Significant research has been conducted on the catalytic hydrogenation of levulinic acid into $\gamma$-valerolactone. Several studies have been focused on homogeneous and heterogeneous catalysts, on ionic liquids, and the use of supercritical $\mathrm{CO}_{2}$ conditions for the production of biomass-derived GVL. ${ }^{[165-167]}$ In the case of homogeneous studies, Heeres et al. ${ }^{[168]}$ report the use of the water-soluble Ru-TPPTS [TPPTS $=\operatorname{tris}(m$-sulfonatophenyl) phosphine trisodium salt] catalyst for the effective hydrogenation of levulinic acid into GVL. To improve the economic viability of the homogeneous process, a possible solution is the use of a biphasic catalysts, for which the catalyst is present in a second, product-immiscible phase after the reaction and is easily separated from the product phase and recycled. ${ }^{[169,170]}$ For that approach, a well-known case in homogeneous hydrogenation reactions is the use of aqueous/organic biphasic systems with the use of water-soluble ruthenium complexes with

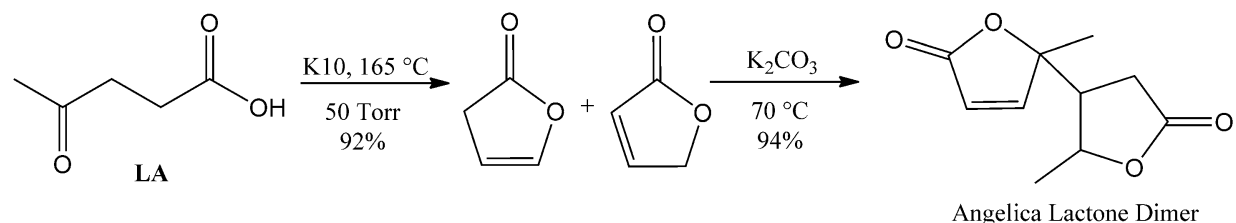

Figure 9. Production of angelica lactone dimer from levulinic acid. ${ }^{[163]} 1 \mathrm{Torr}=133 \mathrm{~Pa}$.

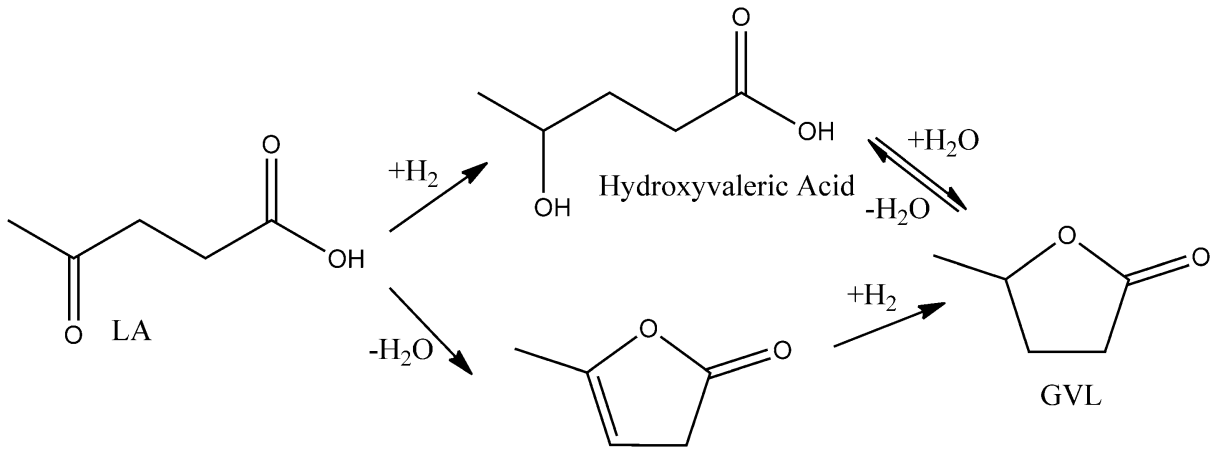

$\alpha$ Angelica Lactone

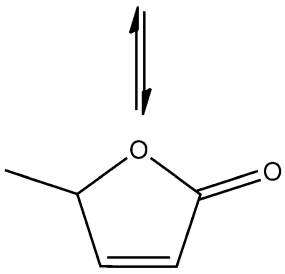

B-Angelica Lactone

Figure 10. Reaction pathways to produce $\gamma$-valerolactone. ${ }^{[161]}$ 
sulfonated phosphine ligands such as sodium tris $(m$-sulfonatophenyl)phosphine. In the case of biphasic homogeneous catalysts, Curtiss et al. ${ }^{[171]}$ report the use of the Shvo catalyst for the catalytic reduction of LA to GVL via 2-hydroxypentanoic acid as an intermediate. Under supercritical conditions, Poliakoff et al. ${ }^{[172]}$ have achieved high yields of GVL $(\approx 99 \%)$ under high-temperature $\left(180-200^{\circ} \mathrm{C}\right)$ and high-pressure $(10-20 \mathrm{MPa})$ reaction conditions.

In terms of heterogeneous catalysts, ruthenium-supported materials have been mentioned in research on the catalytic conversion of LA into GVL. Weckhuysen et al. ${ }^{[173,174]}$ have studied the catalytic performance of ruthenium-supported catalysts, the influence of the solvent, and the acidity of the support (i.e., $\mathrm{Nb}_{2} \mathrm{O}_{5}, \mathrm{TiO}_{2}, \mathrm{H}-\mathrm{b}$, and $\mathrm{H}-\mathrm{ZSM} 5$ ). $\mathrm{Ru} / \mathrm{TiO}_{2}$ gives excellent selectivity to GVL $(97.5 \%)$ at $100 \%$ conversion and is remarkably stable even under severe reaction conditions. $\mathrm{Ru} / \mathrm{H}$ ZSM5 shows a $45.8 \%$ yield of pentanoic acid and its esters in dioxane, which is the first example of this one-pot conversion directly from LA at $473 K_{.}{ }^{[173,174]}$ Ortiz-Cervantes and García ${ }^{[175]}$ have studied the effective hydrogenation of LA to GVL in the presence of ruthenium nanoparticles (Ru-NPs) as heterogeneous catalysts, and they have also tested the efficiency of different solvents. In the presence of $\mathrm{H}_{2} \mathrm{O}$ as the solvent, the Ru-NPs show $99 \%$ yield of $\mathrm{GVL}$, whereas in the presence of $\mathrm{MeOH}$ (under $\mathrm{H}_{2}$ conditions) a high yield of methyl levulinate (59\%) is reported as a reaction byproduct. Other cases of rutheniumsupported catalysts have been studied by Zhang et al ${ }^{[176]}$ (e.g., a Ru/polyethersulfone catalyst) and by Venugopal et al. (e.g., a Ru/hydroxyapatite catalyst). ${ }^{[177]}$ Noble palladium (Pd) nanoparticles have also been testified as efficient hydrogenation catalysts by Yan et al. ${ }^{[178,179]}$ Pd-supported nanoparticles show significant selectivity and are able to produce GVL at $96 \%$ yield at $100 \%$ conversion of levulinic acid. The Pd nanoparticle catalysts exhibit stable catalytic performance over several runs, which is promising for the clean production of chemicals and biofuels from biomass. Conditions for the catalytic hydrogenation of LA into GVL are shown in Table 6.

To reduce the cost of catalytic processes, non-noble metal catalysts have been suggested for improved process economics. Noble-metal-free catalysts have been extensively studied as highly efficient hydrogenation catalysts for the production of GVL by the reduction of LA. Yan and Chen ${ }^{[180,181]}$ report the use of environmental friendly copper catalysts for the hydrogenation of levulinic acid. The reaction is highly selective and gives GVL in $90 \%$ yield at $97.8 \%$ conversion. ${ }^{[180,181]}$ Another advantage of non-noble metal catalysts is reduced leaching. Hengne and Rode ${ }^{[182]}$ have studied the hydrogenation of $\mathrm{LA}$ and its ester over $\mathrm{Cu}-\mathrm{ZrO}_{2}$ and $\mathrm{Cu}-\mathrm{Al}_{2} \mathrm{O}_{3}$ nanocomposites. Between the two catalysts, metal leaching in water is substantially reduced ( $\mathrm{Cu}$ leaching: $34 \mathrm{ppm}$ ) for the $\mathrm{Cu}-\mathrm{ZrO}_{2}$ catalyst relative to the $\mathrm{Cu}-\mathrm{Al}_{2} \mathrm{O}_{3}$ ( $\mathrm{Cu}$ leaching: $174 \mathrm{ppm}$ ) catalyst owing to the formation of stable tetragonal phase $\mathrm{ZrO}_{2}$, which strongly binds to active $\mathrm{Cu}$. Another non-noble metal option studied by Chia and Dumesic ${ }^{[183]}$ involves the use of metal oxides, such as $\mathrm{ZrO}_{2}$ and $\gamma-\mathrm{Al}_{2} \mathrm{O}_{3}$ to produce GVL by transfer hydrogenation through the Meerwein-Ponndorf-Verly reaction by using secondary alcohols as the solvent and hydrogen donor. The highest yield of GVL (92\%) is achieved with 2-butanol and $\mathrm{ZrO}_{2}$. A significant issue regarding the effectiveness of the process is the economics of the noble and non-noble metal catalysts. The economics of the noble and non-noble metal catalysts is a significant issue with regard to the effectiveness of the hydrogenation process. Palkovits et al. ${ }^{[184]}$ report that the production of GVL heavily relies on the use of noble metals, which

\begin{tabular}{|c|c|c|c|}
\hline Conditions & Biomass precursor & GVL yield [\%] & Ref. \\
\hline RU-TPPTS, ${ }^{[a]} 2 \mathrm{~h}, 115^{\circ} \mathrm{C}$ & levulinic acid & 80 & [169] \\
\hline $\mathrm{Ru} / \mathrm{SiO}_{2}$ under supercritical $\mathrm{CO}_{2}, 10-20 \mathrm{MPa}, 115^{\circ} \mathrm{C}$ & levulinic acid & 99 & [172] \\
\hline $\mathrm{Ru} / \mathrm{H}-\beta$ in dioxane, $10 \mathrm{~h}, 200^{\circ} \mathrm{C}$ & levulinic acid & 40.5 & [173] \\
\hline \multicolumn{4}{|l|}{$\mathrm{H}-\mathrm{ZSM} 5,4 \mathrm{~h}, 200^{\circ} \mathrm{C}$} \\
\hline $\mathrm{Ru} / \mathrm{TiO}_{2}, 10 \mathrm{~h}, 200^{\circ} \mathrm{C}$ & levulinic acid & 91.6 & [174] \\
\hline \multirow{2}{*}{ Ru-NPs in water, methanol, or THF, $130^{\circ} \mathrm{C}$} & & 98 (in THF) & \\
\hline & & 41 (in $\mathrm{MeOH}$ ) & \\
\hline $\mathrm{Ru} /$ polyethersulfone, $2 \mathrm{~h}, 130^{\circ} \mathrm{C}$ & levulinic acid & 85 & [176] \\
\hline \multirow[t]{3}{*}{$\mathrm{Ru} /$ hydroxyapatite, water, ethanol/water or toluene, $4 \mathrm{~h}, 70^{\circ} \mathrm{C}$} & levulinic acid & 99 (in water) & [177] \\
\hline & & 75.4 (in water/toluene) & \\
\hline & & 27.6 (in toluene) & \\
\hline $\mathrm{Pd} / \mathrm{SiO}_{2}, 6 \mathrm{~h}, 160^{\circ} \mathrm{C}$ & levulinic acid & 8.2 (1 wt \% catalyst) & [178] \\
\hline $\mathrm{Pd} / \mathrm{MCM}-41,6$ to $10 \mathrm{~h}, 140$ to $240^{\circ} \mathrm{C}$ & & $85.2\left(6 \mathrm{~h} / 240^{\circ} \mathrm{C}\right)$ & \\
\hline Cu-Fe catalyst, $\mathrm{H}_{2}(9.0 \mathrm{MPa}), 14 \mathrm{~h}, 220^{\circ} \mathrm{C}$ & levulinic acid & 50.8 & [180] \\
\hline \multirow[t]{2}{*}{ Cu-Cr catalyst, $\mathrm{H}_{2}$ (3.5 to $7.0 \mathrm{MPa}$ ), 3 to $6 \mathrm{~h}, 120$ to $220^{\circ} \mathrm{C}$} & levulinic acid & $3.2\left(3 \mathrm{~h} / 140^{\circ} \mathrm{C}\right)$ & [181] \\
\hline & & $74.7\left(3 \mathrm{~h} / 220^{\circ} \mathrm{C}\right)$ & \\
\hline \multirow[t]{2}{*}{$\mathrm{Cu}-\mathrm{ZrO}_{2}$ or $\mathrm{Cu}-\mathrm{Al}_{2} \mathrm{O}_{3}, 5 \mathrm{~h}, 200^{\circ} \mathrm{C}$} & levulinic acid & $90\left(\mathrm{Cu}-\mathrm{ZrO}_{2}\right)$ & [182] \\
\hline & & $86\left(\mathrm{Cu}-\mathrm{Al}_{2} \mathrm{O}_{3}\right)$ & \\
\hline \multirow[t]{2}{*}{$\mathrm{ZrO}_{2}$ or $\mathrm{MgO} / \mathrm{ZrO}_{2}, 16 \mathrm{~h}, 160^{\circ} \mathrm{C}$} & levulinic acid & $92\left(\mathrm{ZrO}_{2}\right)$ & [183] \\
\hline & & $54\left(\mathrm{MgO} / \mathrm{ZrO}_{2}\right)$ & \\
\hline
\end{tabular}


could be a significant problem in the case of scale up because of their costs and the uncertainty in their future availability. Graedel et al. ${ }^{[185-189]}$ report that although the availability of base metals such as $\mathrm{Al}, \mathrm{Cu}, \mathrm{Ni}, \mathrm{Sn}$, and so on will not be a problem in the future, the increasing use of rare metals such as $\mathrm{Ru}$, $\mathrm{Rh}, \mathrm{Pd}$, and Re may jeopardize their future availability. Replacement of noble metals by nonprecious and more widely available metals, and the recovery and recycling of the metal, will become important issues in the future. Finally, the next step will be the conversion of GVL through various catalytic processes into 1,4-pentanediol, 2-methyltetrahydrofuran, valeric biofuels, and 5-nonanone with potential applications in the fuels industry and as precursors for the production of alkanes with different chain lengths for fuel, biodiesel, and gasoline additives.

\section{Catalytic Conversion of $\gamma$-Valerolactone into Valuable Chemicals and Fuels}

\subsection{1,4-Pentanediol and 2-methyltetrahydrofuran}

GVL can be directly used as a liquid fuel or as an additive in current petroleum fuels, similar to ethanol. Horváth et al. ${ }^{[190]}$ report the use of GVL in a 90:10 mixture of conventional gasoline/GVL or $10 \%$ ethanol, observing improved combustion with lower vapor pressure at similar octane numbers. GVL has combustion energy $\left(29.7 \mathrm{MJ} \mathrm{kg}^{-1}\right)$ similar to that of ethanol and higher energy density. ${ }^{[190]}$ The main problem of GVL as a pure fuel is its high water solubility.

GVL can be further hydrogenated to produce fuel additives such as 1,4-pentanediol (1,4-PDO) and 2-methyltetrahydrofuran (MTHF; Figure 11). Palkovits et al. ${ }^{[191]}$ report the solvent-fee hydrogenation of GVL into MTHF in the presence of a Ru/C catalyst. The highest selectivity for MTHF is achieved at $190^{\circ} \mathrm{C}$ after a reaction time of $24 \mathrm{~h}$ (conversion: $99 \%$, MTHF yield: $43 \%$ ). Little attention has been focused on the involved reaction pathways. Their study focuses on the influence of reaction conditions in the heterogeneous-catalyzed hydrogenation mechanism of GVL into MTHF. Du et al. ${ }^{[192]}$ have used an inexpensive Cu catalyst and have converted GVL into MTHF with a GVL/ MTHF conversion selectivity ratio of 98:93. A decrease in the reaction temperature and the use of a calcined $\mathrm{Cu}$ catalyst in the presence of $\mathrm{H}_{2}$ (instead of air) leads to the formation of 1,4-pentanediol. These results show that control of the reaction conditions can lead to different hydrogenation products. ${ }^{[192]}$ Elliott and Frye ${ }^{[193]}$ report the transformation of LA into MTHF by using 1,4-dioxane and water as solvents. They have tested noble metals as catalysts for the reaction of LA into
MTHF, with GVL and 1,4-PDO as intermediates. Homogeneous ruthenium catalysts have also been studied for the efficient conversion of LA into GVL and then into MTHF. ${ }^{[190,194]}$

\subsection{Valeric biofuels and 5-nonanone}

As shown in Figure 12, GVL can undergo different catalytic reaction pathways for the production of various molecularweight alkanes as liquid hydrocarbon fuels. For the production of liquid fuels, GVL can be converted by two different routes: One, a ring-opening reaction of GVL results in the formation of pentenoic acid. Further decarboxylation of pentenoic acid leads to the formation of butenes, a monomer precursor for the production $C_{8}$ alkanes. Two, a combination of ring opening/hydrogenation leads to the formation of pentanoic acid. Significant research has been focused on the catalytic upgrading of pentanoic acid into valeric biofuels as fuel additives and in the ketonization of pentanoic acid into 5-nonanone, a valuable monomer for the production of higher molecular weight alkanes $\left(C_{18}-C_{27}\right.$ alkanes) that can be used as diesel fuels. ${ }^{[60]}$

Lange et al. ${ }^{[195]}$ report the synthesis of new LA derivatives, the "valeric biofuels", which are gasoline and diesel components fully compatible with transportation fuels, in a two-step process. They report the conversion of GVL into pentanoic acid over a bifunctional metal-acid catalyst (Pt/ZSM-5). In the next step, esterification of pentanoic acid into valerate ester is performed in the presence of alcohols and solid-acid catalysts. Yields of pentanoic over $90 \%$ are achieved in the presence of Pt bifunctional catalysts. Zaccheria et al. ${ }^{[196]}$ report the singlestep production of pentyl valerate from GVL in the presence of a Cu-supported $\left(\mathrm{SiO}_{2}-\mathrm{ZrO}_{2}\right)$ catalyst in pentanol as the solvent. They also perform the synthesis of valeric esters in the presence of ethanol and report the formation of ethyl 4-ethoxypentanoate as the main byproduct. ${ }^{[196]}$

To upgrade GVL into liquid fuels, its molecular weight needs to be increased and the oxygen content should be decreased. Instead of esterification of pentanoic acid, Serrano-Ruiz ${ }^{[197]}$ reports the ketonization of pentanoic acid into 5-nonanone. An overall yield of $84 \%$ of 5 -nonanone is obtained in the presence of a CeZrO ${ }_{x}$ catalyst. They also report the use of $\mathrm{Pd} / \mathrm{Nb}_{2} \mathrm{O}_{5}$ for the efficient conversion of GVL into pentanoic acid versus 5nonanone. The upgrading of 5-nonanone produced from GVL has many possibilities for valuable alkane liquid fuels. 5-Nonanone can be converted into nonane by hydrogenation and dehydration reactions over metal-acid catalysts. Nonane can be used as a fuel additive to diesel, and it can undergo isomerization and aromatization over zeolites to produce $C_{9}$ olefins. $C_{9}$

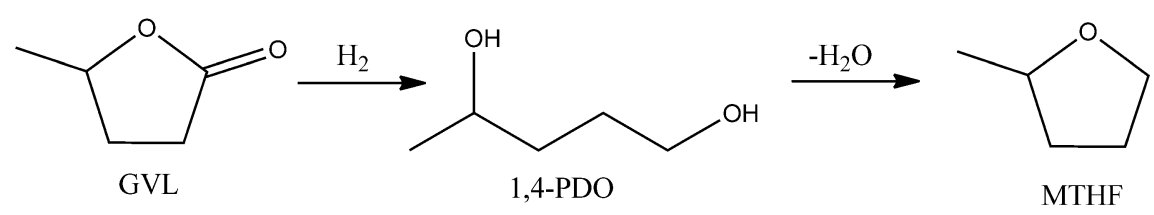

Figure 11. Conversion of 1,4-PDO and MTHF from GVL. ${ }^{[191]}$ 


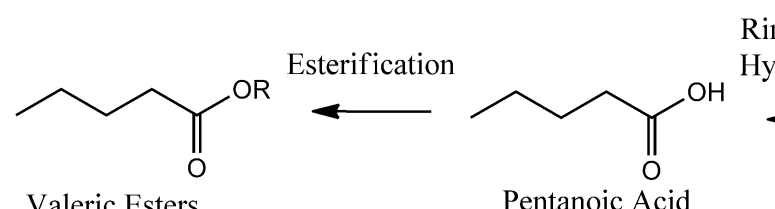

Valeric Esters
Ring Opening/

Hydrogenation

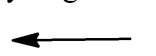<smiles>CC1CCC(=O)O1</smiles>

GVL<smiles>[R16]O[R16](C)=CCC=CCC(=O)O</smiles>

Pentenoic Acid

Decarboxylation<smiles>CC=CC</smiles>

Oligomerization/ Hydrogenation

Hydrogenation

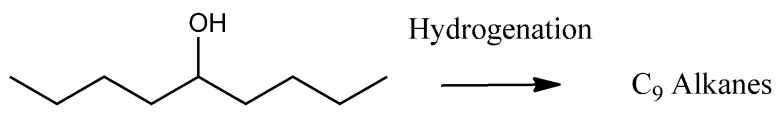

5-Nonanol

Dehydration

Oligomerization/<smiles>CCCC=CCCCC</smiles>

Hydrogenation<smiles>C/C=C/CCCCCCCC</smiles>

$\longrightarrow \quad \mathrm{C}_{18}-\mathrm{C}_{27}$ Alkanes

Figure 12. Reaction pathways for the production of targeted molecular weight alkanes by catalytic upgrading of GVL. ${ }^{\text {196-198] }}$

alkanes can be oligomerized over acid catalysts for the production of higher molecular weight $\mathrm{C}_{18}-\mathrm{C}_{27}$ alkanes. ${ }^{[60,198]}$

\section{3. $\alpha$-Methylene- $\gamma$-valerolactone}

Instead of renewable fuels, GVL can be used to synthesize interesting monomers to produce polymers similar to those derived from petroleum but with different chemical properties. $\alpha$-Methylene- $\gamma$-valerolactone (MeMBL) is an attractive acrylic monomer that transmits high thermal stability to polymers. MeMBL (Figure 13) has a structure similar to that of methyl methacrylate, but by adding the lactone structure into the polymeric chain, the glass-transition temperature of the homopolymer is $100^{\circ} \mathrm{C}$ higher than that of polymethyl methacrylate. ${ }^{[199]}$ Manzer ${ }^{[199]}$ has studied the synthesis of MeMBL from GVL with formaldehyde over a heterogeneous catalyst in the gas phase. Several issues regarding the problematic synthesis of MeMBL have also been reported. The high boiling temperature of the materials, the rapid polymerization of MeMBL, and the difficulty to handle formaldehyde in the gas phase have also been reported.

A summary of GVL derivatives and their potential applications is shown in Figure 14.

\section{Conclusions}

Over the last centuries, our society has become heavily dependent on petroleum as a source to produce chemicals and fuels. The increasing demand for energy sources and the challenge of $\mathrm{CO}_{2}$ emissions affecting earth's climate have led efforts to find renewable substitutes for petroleum-derived products. For this reason, research has focused on using biomass as an alternative carbon source, as it offers multiple advantages over petroleum. Levulinic acid (LA) is a promising renewable platform molecule for the synthesis of several chemicals for applications such as fuel additives, fragrances, solvents, oil additives, pharmaceuticals, and plasticizers. ${ }^{[2,14-16]}$ Levulinic acid can be produced from lignocellulosic biomass by dehydration of biomass

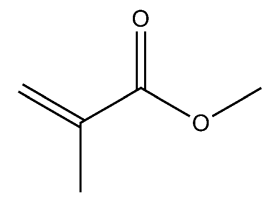

Methyl Methacrylate (MMA)

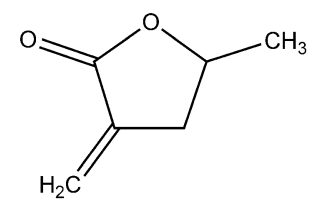

$\alpha$-Methylene- $\gamma$-Valerolactone
Figure 13. Chemical structure of methyl methacrylate and $\alpha$-methylene- $\gamma$-valerolactone. 


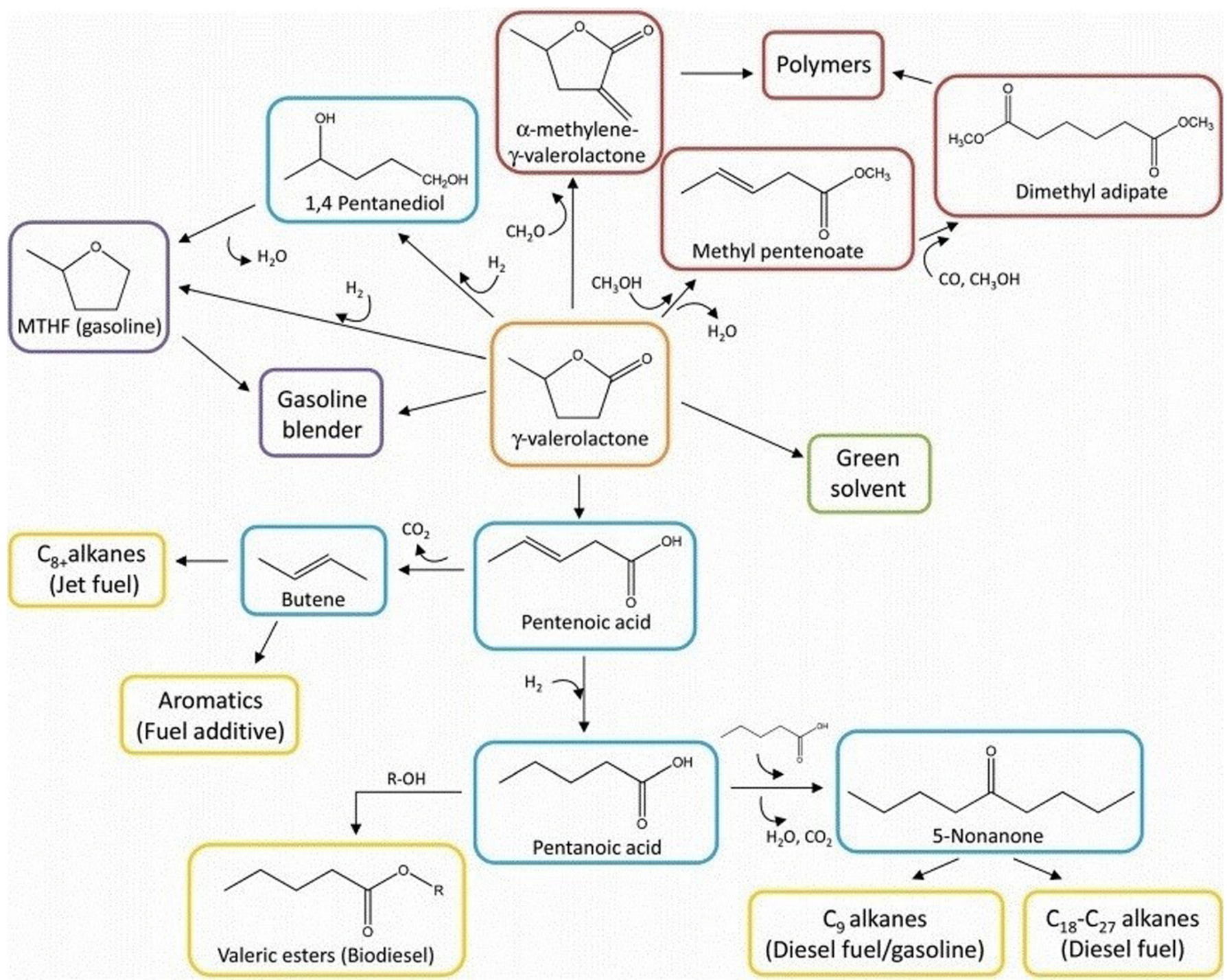

Figure 14. GVL derivatives and their potential applications. ${ }^{[164]}$

sugars (glucose) into HMF and further hydrolysis of HMF into formic and levulinic acid. LA has been classified as one of the top value-added chemicals from biomass by the National Renewable Energy Laboratory and the United States Department of Energy. Levulinic acid can be upgraded to a variety of chemicals with main applications in the areas of fuels and fuel additives. Different catalytic pathways can lead to the synthesis of levulinate esters, $\gamma$-valerolactone, and various molecular weight alkanes (mainly $C_{9}$ and $C_{18}-C_{27}$ olefins), which can be used as fuels and diesel and fuel additives. $\gamma$-Valerolactone can also be used as a solvent or gasoline blender and in the production of valuable monomers. Several industrial and university-based projects show the significance of levulinic acid as a potential feedstock in the economy of biobased chemicals. Companies such as GFBiochemicals, Segetis, and Avantium have already introduced the use of levulinic acid for the production of several biobased chemicals on the industrial and commercial scales, and this offers new opportunities to replace petroleum-derived chemicals and fuels with biomass-derived options.

Summarizing all the information provided above, it is clear that several major opportunities and advantages have been studied and considered during the production and use of levulinic acid from biomass: one, levulinic acid is a promising platform molecule that can be produced directly from lignocellulosic biomass sources; two, levulinic acid provides a variety of alkanes with different chain lengths as fuels, so technoeconomic analyses of different alkane pathways will be critical to determine the feasibility and effectiveness of these products as fuel additives and substitutes to petroleum-derived products; three, levulinic acid upgrade technologies still require improvement to produce pure and cost-competitive products (fuels and chemicals); four, the design and use of efficient heterogeneous catalysts with high cyclability to avoid homogeneous mineral acids; five, further improvements in selectivity and catalyst lifetime are needed. Hence, more chemical, catalysis, and engineering research is valuable to realize the potential of lev- 
ulinic acid biorefineries and to optimize their potential for the manufacture of fuels and chemicals.

Keywords: biomass - biorefineries - energy conversion nanotechnology $\cdot$ platform chemicals

[1] R. A. Sheldon, Catal. Today 2011, 167, 3-13.

[2] F. H. Isikgor, C. R. Becer, Polym. Chem. 2015, 6, 4497-4559.

[3] R. Weingarten, G. A. Tompsett, W. C. Conner, Jr., G. W. Huber, J. Catal. 2011, 279, 174-182.

[4] B. Girisuta, Doctor of Philosophy, University of Groningen, 2007.

[5] A. Verma, S. Kumar, P. K. Jain, J. Sci. Res. 2011, 55, 57-63.

[6] M. Galbe, G. Zacchi in Biofuels, Vol. 108 (Ed. L. Olsson), Springer, Berlin, 2007, ch. 70, pp. $41-65$

[7] R. Rinaldi, F. Schüth, ChemSusChem 2009, 2, 1096-1107.

[8] J. C. Serrano-Ruiz, R. Luque, A. Sepulveda-Escribano, Chem. Soc. Rev. 2011, 40, 5266-5281.

[9] D. M. Alonso, J. Q. Bond, J. A. Dumesic, Green Chem. 2010, 12, 1493 1513.

[10] B. Holmbom in Analytical Methods in Wood Chemistry, Pulping, and Papermaking (Eds.: E. Sjöström, R. Alén), Springer, Berlin, 1999, ch. 5, pp. $125-148$.

[11] J. Zakzeski, P. C. A. Bruijnincx, A. L. Jongerius, B. M. Weckhuysen, Chem. Rev. 2010, 110, 3552-3599.

[12] G. Centi, P. Lanzafame, S. Perathoner, Catal. Today 2011, 167, 14-30.

[13] J.-P. Lange, E. van der Heide, J. van Buijtenen, R. Price, ChemSusChem 2012, 5, 150-166.

[14] J. J. Bozell, G. R. Petersen, Green Chem. 2010, 12, 539-554.

[15] J. C. Serrano-Ruiz, J. A. Dumesic, Energy Environ. Sci. 2011, 4, 83-99.

[16] E. I. Gürbüz, D. M. Alonso, J. Q. Bond, J. A. Dumesic, ChemSusChem 2011, 4, 357-361.

[17] J.-P. Lange, W. D. van de Graaf, R. J. Haan, ChemSusChem 2009, 2, 437 441.

[18] Avantium, http://www.avantium.com/.

[19] A. Caretto, A. Perosa, ACS Sustainable Chem. Eng. 2013, 1, 989-994.

[20] J. N. Chheda, Y. Roman-Leshkov, J. A. Dumesic, Green Chem. 2007, 9, $342-350$.

[21] X. Qi, M. Watanabe, T. M. Aida, R. L. Smith, Jr., Catal. Commun. 2008, 9, 2244-2249.

[22] J. Lewkowski, Arkivoc 2001, 17-54.

[23] R. Palkovits, K. Tajvidi, A. M. Ruppert, J. Procelewska, Chem. Commun. 2011, 47, 576-578.

[24] A. Fukuoka, P. L. Dhepe, Angew. Chem. Int. Ed. 2006, 45, 5161-5163; Angew. Chem. 2006, 118, 5285-5287.

[25] N. Ji, T. Zhang, M. Zheng, A. Wang, H. Wang, X. Wang, J. G. Chen, Angew. Chem. Int. Ed. 2008, 47, 8510-8513; Angew. Chem. 2008, 120, $8638-8641$.

[26] B. Girisuta, B. Danon, R. Manurung, L. P. B. M. Janssen, H. J. Heeres, Bioresour. Technol. 2008, 99, 8367-8375.

[27] J. Y. Cha, M. A. Hanna, Ind. Crops Prod. 2002, 16, 109-118.

[28] C. Chang, P. Cen, X. Ma, Bioresour. Technol. 2007, 98, 1448-1453.

[29] A. Mukherjee, M.-J. Dumont, V. Raghavan, Biomass Bioenergy 2015, 72, $143-183$.

[30] L. Peng, L. Lin, J. Zhang, J. Zhuang, B. Zhang, Y. Gong, Molecules 2010, $15,5258$.

[31] D. W. Rackemann, W. O. S. Doherty, Biofuels Bioprod. Biorefin. 2011, 5, $198-214$.

[32] H. Chen, B. Yu, S. Jin, Bioresour. Technol. 2011, 102, 3568-3570.

[33] K. Wilson, J. H. Clark, K. Wilson, J. H. Clark, Pure Appl. Chem. 2000, 72, $1313-1319$.

[34] D. M. Alonso, S. G. Wettstein, M. A. Mellmer, E. I. Gurbuz, J. A. Dumesic, Energy Environ. Sci. 2013, 6, 76-80.

[35] L. Qi, Y. F. Mui, S. W. Lo, M. Y. Lui, G. R. Akien, I. T. Horváth, ACS Catal. 2014, 4, 1470-1477.

[36] L. Qi, I. T. Horváth, ACS Catal. 2012, 2, 2247-2249.

[37] M. A. Mellmer, J. M. R. Gallo, D. Martin Alonso, J. A. Dumesic, ACS Catal. 2015, 5, 3354-3359.

[38] D. M. Alonso, J. M. R. Gallo, M. A. Mellmer, S. G. Wettstein, J. A. Dumesic, Catal. Sci. Technol. 2013, 3, 927-931.
[39] P. P. Upare, J.-W. Yoon, M. Y. Kim, H.-Y. Kang, D. W. Hwang, Y. K. Hwang, H. H. Kung, J.-S. Chang, Green Chem. 2013, 15, 2935-2943.

[40] Y. Zuo, Y. Zhang, Y. Fu, ChemCatChem 2014, 6, 753-757.

[41] Bin Y., Hongzhang C., Bioresour. Technol 2010, 101, 9114-9119..

[42] A. M. R. Galletti, C. Antonetti, V. De Luise, G. Valentini.

[43] L. J. Carlson, (Rayonier Inc., Jacksonville, FL, US), US3065263A, 1962.

[44] A. P. Dunlop, (Quaker Oats Co., Chicago, IL, US), US2684982A, 1954.

[45] F. Seibert, (MeadWestvaco Corp., Richmond, VA, US), WO2010030617A1, 2010.

[46] J. L. W. C. Den Boestert, J. P. Haan, A. Nijmeijer, (Shell Oil Company, Houston, TX, US), US7501062B2, 2009.

[47] S. Xiao, B. Liu, Y. Wang, Z. Fang, Z. Zhang, Bioresour. Technol. 2014, $151,361-366$

[48] A. Morone, M. Apte, R. A. Pandey, Renewable Sustainable Energy Rev. $2015,51,548-565$.

[49] D. J. Hayes, S. Fitzpatrick, M. H. B. Hayes, J. R. H. Ross in Biorefineries Industrial Processes and Products: Status Quo and Future Directions (Eds.: B. Kamm, P. R. Gruber, M. Kamm), Wiley-VCH, Weinheim, 2008, pp. $139-164$.

[50] T. Alva, (Corn Products Refining Co., New York, NY, US), US2206311A, 1940.

[51] D. J. Hayes, Catal. Today 2009, 145, 138-151.

[52] H. Joshi, B. R. Moser, J. Toler, W. F. Smith, T. Walker, Biomass Bioenergy 2011, 35, 3262-3266.

[53] S. O. Edwin, R. K. Michelle, J. S. Adam, K. S. Ramesh in ACS Symposium Series Vol. 784: Chemicals and Materials from Renewable Resources, (Ed.: J. J. Bozell), American Chemical Society, Washington, DC, 2001, ch. 5, pp. $51-63$.

[54] A. Démolis, N. Essayem, F. Rataboul, ACS Sustainable Chem. Eng. 2014, 2, 1338-1352

[55] M. J. Climent, A. Corma, S. Iborra, Green Chem. 2014, 16, 516-547.

[56] J. Q. Bond, A. A. Upadhye, H. Olcay, G. A. Tompsett, J. Jae, R. Xing D. M. Alonso, D. Wang, T. Zhang, R. Kumar, A. Foster, S. M. Sen, C. T. Maravelias, R. Malina, S. R. H. Barrett, R. Lobo, C. E. Wyman, J. A. Dumesic, G. W. Huber, Energy Environ. Sci. 2014, 7, 1500-1523.

[57] S. G. Wettstein, D. M. Alonso, E. I. Gürbüz, J. A. Dumesic, Curr. Opin. Chem. Eng. 2012, 1, 218-224.

[58] S. Murat Sen, C. A. Henao, D. J. Braden, J. A. Dumesic, C. T. Maravelias, Chem. Eng. Sci. 2012, 67, 57-67.

[59] I. Delidovich, K. Leonhard, R. Palkovits, Energy Environ. Sci. 2014, 7 , $2803-2830$

[60] D. M. Alonso, J. Q. Bond, J. C. Serrano-Ruiz, J. A. Dumesic, Green Chem. 2010, 12, 992-999.

[61] K. S. Bankole, Doctor of Philosophy, University of lowa, 2011.

[62] A. Z. Fadhel, P. Pollet, C. L. Liotta, C. A. Eckert, Molecules 2010, 15, 8400 .

[63] H. J. Bart, J. Reidetschlager, K. Schatka, A. Lehmann, Ind. Eng. Chem. Res. 1994, 33, $21-25$.

[64] K. Garves, J. Wood Chem. Technol. 1988, 8, 121-134.

[65] F. D. Pileidis, M. Tabassum, S. Coutts, M.-M. Titirici, Chin. J. Catal. 2014, 35, 929-936.

[66] W. Deng, Q. Zhang, Y. Wang, Sci. China Chem. 2015, 58, 29-46.

[67] T. V. Ojumu, O .A. Ogunkunle, J. Appl. Sciences, 2005, 5, 15-17.

[68] Y. Wang, X. Nie, Z. Liu, J. Chem. Ind. Forest Prod. 2011, 31, 23-27.

[69] W. Zhu, C. Chang, C. Ma, F. Du, Chin. J. Chem. Eng. 2014, 22, 238-242.

[70] L. Peng, L. Lin, H. Li, Ind. Crops Prod. 2012, 40, 136-144.

[71] H. Li, L. Peng, L. Lin, K. Chen, H. Zhang, J. Energy Chem. 2013, 22, 895 901.

[72] L. Peng, H. Li, L. Xi, K. Chen, H. Chen, BioResources 2014, 9, 3825 3834.

[73] R. Le Van Mao, Q. Zhao, G. Dima, D. Petraccone, Catal. Lett. 2011, 141, $271-276$.

[74] Z. Zhang, K. Dong, Z. Zhao, ChemSusChem 2011, 4, 112-118.

[75] K. Garves, DE3621517A1, 1988.

[76] D. Bianchi, A. M. Romano, (Eni S.p.A., Rome, IT), WO2009156842A1, 2009.

[77] R. Le Van Mao, (AC3B Technologies Ltd., Ville Saint-Laurent, QC, CA), WO2013127006A1, 2013.

[78] R. Le Van Mao, A. Muntasar, D. Petraccone, H. T. Yan, Catal. Lett. 2012 $142,667-675$ 
[79] Y. Hishikawa, M. Yamaguchi, S. Kubo, T. Yamada, J. Wood Sci. 2013, 59, $179-182$.

[80] C. Chang, G. Xu, X. Jiang, Bioresour. Technol. 2012, 121, 93-99.

[81] W. E. Lawson, P. L. Salzberg, (DuPont, Wilmington, DE, US), US2008720A, 1935

[82] S. K. Bhorodwaj, D. K. Dutta, Appl. Catal. A 2010, 378, 221 - 226.

[83] G. D. Yadav, Catal. Surv. Asia 2005, 9, 117-137.

[84] K. Y. Nandiwale, S. K. Sonar, P. S. Niphadkar, P. N. Joshi, S. S. Deshpande, V. S. Patil, V. V. Bokade, Appl. Catal. A 2013, 460-461, 90-98.

[85] K. Y. Nandiwale, P. S. Niphadkar, S. S. Deshpande, V. V. Bokade, J. Chem. Technol. Biotechnol. 2014, 89, 1507-1515.

[86] K. Yan, G. Wu, J. Wen, A. Chen, Catal. Commun. 2013, 34, 58-63.

[87] G. Pasquale, P. Vázquez, G. Romanelli, G. Baronetti, Catal. Commun. 2012, 18, 115-120

[88] H. Gurav, V. V. Bokade, J. Nat. Gas Chem. 2010, 19, 161-164.

[89] J. C. Groen, T. Sano, J. A. Moulijn, J. Pérez-Ramírez, J. Catal. 2007, 251, $21-27$.

[90] C. R. Patil, P. S. Niphadkar, V. V. Bokade, P. N. Joshi, Catal. Commun. 2014, 43, 188-191.

[91] K. Maheria, J. Kozinski, A. Dalai, Catal. Lett. 2013, 143, 1220-1225.

[92] J. A. Melero, G. Morales, J. Iglesias, M. Paniagua, B. Hernández, S. Penedo, Appl. Catal. A 2013, 466, 116-122.

[93] B. L. Oliveira, V. Teixeira da Silva, Catal. Today 2014, 234, 257-263.

[94] D. R. Fernandes, A. S. Rocha, E. F. Mai, C. J. A. Mota, V. Teixeira da Silva, Appl. Catal. A 2012, 425-426, 199-204.

[95] Z. Li, R. Wnetrzak, W. Kwapinski, J. J. Leahy, ACS Appl. Mater. Interfaces 2012, 4, 4499-4505.

[96] Y. Kuwahara, W. Kaburagi, K. Nemoto, T. Fujitani, Appl. Catal. A 2014 476, 186- 196.

[97] V. L. Budarin, J. H. Clark, R. Luque, D. J. Macquarrie, Chem. Commun. 2007, 634-636.

[98] C. de La Calle, J. M. Fraile, E. Garcia-Bordeje, E. Pires, L. Roldan, Catal. Sci. Technol. 2015, 5, 2897-2903.

[99] P. Valle-Vigón, M. Sevilla, A. B. Fuertes, Appl. Surf. Sci. 2012, 261, 574 583.

[100] R. Liu, J. Chen, X. Huang, L. Chen, L. Ma, X. Li, Green Chem. 2013, 15, $2895-2903$

[101] C.-H. Kuo, A. S. Poyraz, L. Jin, Y. Meng, L. Pahalagedara, S.-Y. Chen, D. A. Kriz, C. Guild, A. Gudz, S. L. Suib, Green Chem. 2014, 16, 785-791.

[102] S. Saravanamurugan, O. Nguyen Van Buu, A. Riisager, ChemSusChem 2011, 4, 723-726.

[103] S. Saravanamurugan, A. Riisager, Catal. Commun. 2012, 17, 71- 75.

[104] S. Saravanamurugan, A. Riisager, ChemCatChem 2013, 5, 1754-1757.

[105] G. Morales, A. Osatiashtiani, B. Hernandez, J. Iglesias, J. A. Melero, M. Paniagua, D. Robert Brown, M. Granollers, A. F. Lee, K. Wilson, Chem. Commun. 2014, 50, 11742-11745.

[106] P. Neves, M. M. Antunes, P. A. Russo, J. P. Abrantes, S. Lima, A. Fernandes, M. Pillinger, S. M. Rocha, M. F. Ribeiro, A. A. Valente, Green Chem. 2013, 15, 3367-3376.

[107] W. Deng, M. Liu, Q. Zhang, Y. Wang, Catal. Today 2011, 164, 461-466.

[108] S. Dora, T. Bhaskar, R. Singh, D. V. Naik, D. K. Adhikari, Bioresour. Technol. 2012, 120, 318-321.

[109] P. A. Russo, M. M. Antunes, P. Neves, P. V. Wiper, E. Fazio, F. Neri, F. Barreca, L. Mafra, M. Pillinger, N. Pinna, A. A. Valente, J. Mater. Chem. A 2014, 2, 11813-11824.

[110] F. Rataboul, N. Essayem, Ind. Eng. Chem. Res. 2011, 50, 799-805.

[111] K.-i. Tominaga, A. Mori, Y. Fukushima, S. Shimada, K. Sato, Green Chem. 2011, 13, 810-812.

[112] L. Zhou, H. Zou, J. Nan, L. Wu, X. Yang, Y. Su, T. Lu, J. Xu, Catal. Commun. 2014, 50, 13-16.

[113] E. Lotero, K. Fjare, C. B. Phillips, A. Platon, (Phillips 66 Co., Houston, TX, USA), US20140350292A1, 2014

[114] A. P. Dunlop, G. W. Huffman, (Quaker Oats Co., Chicago, IL, US), US3358014A, 1967

[115] J.P. Lange, W.D. Van de Graaf, (Shell Oil Co., Houston, TX, US), US7265239B2, 2007.

[116] P. Neves, S. Lima, M. Pillinger, S. M. Rocha, J. Rocha, A. A. Valente, Catal. Today 2013, 218-219, 76-84

[117] G. M. González Maldonado, R. S. Assary, J. A. Dumesic, L. A. Curtiss, Energy Environ. Sci. 2012, 5, 8990-8997.
[118] A. C. Cole, J. L. Jensen, I. Ntai, K. L. T. Tran, K. J. Weaver, D. C. Forbes, J. H. Davis, J. Am. Chem. Soc. 2002, 124, 5962-5963.

[119] X. Liang, J. Yang, Green Chem. 2010, 12, $201-204$.

[120] A. M. Hengne, S. B. Kamble, C. V. Rode, Green Chem. 2013, 15, $2540-$ 2547.

[121] G. Wang, Z. Zhang, L. Song, Green Chem. 2014, 16, 1436-1443.

[122] A. E. V. Petersson, L. M. Gustafsson, M. Nordblad, P. Borjesson, B. Mattiasson, P. Adlercreutz, Green Chem. 2005, 7, 837-843.

[123] G. D. Yadav, I. V. Borkar, Ind. Eng. Chem. Res. 2008, 47, 3358-3363.

[124] A. Lee, N. Chaibakhsh, M. B. A. Rahman, M. Basri, B. A. Tejo, Ind. Crops Prod. 2010, 32, 246-251.

[125] A. L. Zanghellini, (Arzeda Corp., Seattle, WA, US), WO2012030860A1, 2012.

[126] K. D. Gibson, W. G. Laver, A. Neuberger, Biochem. J. 1958, 70, $71-81$.

[127] S. I. Beale, S. P. Gough, S. Granick, Proc. Natl. Acad. Sci. USA 1975, 72, 2719-2723.

[128] J. Chen, G. W. Miller, J. Y. Takemoto, Arch. Biochem. Biophys. 1981, 208, $221-228$.

[129] A. R. Constantin, S. Amindari, N. R. Krishna, B. N. Ujjana, M. B. Moubarak, J. A. Velu in ACS Symposium Series, Vol. 559: Porphyric Pesticides: Chemistry, Toxicology, and Pharmaceutical Applications (Eds.: S. O. Duke, C. A. Rebeiz), American Chemical Society, Washington, DC, 1994 ch. 4, pp. 48-64.

[130] Q. Peng, K. Berg, J. Moan, M. Kongshaug, J. M. Nesland, Photochem Photobiol. 1997, 65, 235-251.

[131] S. F. MacDonald, Can. J. Chem. 1974, 52, 3257-3258.

[132] H.-J. Ha, S.-K. Lee, Y.-J. Ha, J.-W. Park, Synth. Commun. 1994, 24, 2557 2562.

[133] L. Moens, (Midwest Research Inst., Kansas City, MO, US), US6583317B1, 2003.

[134] T. Werpy, G. Petersen, Top Value Added Chemicals from Biomass: Vol. I-Results of Screening for Potential Candidates from Sugars and Synthesis Gas, http://www.nrel.gov/docs/fy04osti/35523.pdf, 2004.

[135] C. Delhomme, D. Weuster-Botz, F. E. Kuhn, Green Chem. 2009, 11, 13 26.

[136] L. Volkel, A. Lange, C. Lockemann, D. Posselt, (BASF AG, Ludwigshafen, DE), US20090235576A1, 2009.

[137] Y. Tachibana, T. Masuda, M. Funabashi, M. Kunioka, Biomacromolecules 2010, 11, 2760-2765.

[138] H. Choudhary, S. Nishimura, K. Ebitani, Appl. Catal. A 2013, 458, 55-62.

[139] N. R. Luman, T. Kim, M. W. Grinstaff, Pure Appl. Chem. 2004, 76, 1375.

[140] W. S. Carey, W. C. Ehrhardt, D. T. Freese, L. A. Perez, A. Solov, (BetzDearborn Europe, Inc., Trevose, PA, US), EP0628539B1, 1999.

[141] A. P. Dunlop, S. Shelbert, (Quaker Oats Co., Chicago, IL, US), US2676186A, 1954.

[142] D. S. van Es, F. van der Klis, J. van Haveren, (Stichting Dienst Landbouwkundig, NL), WO2012044168A1, 2012.

[143] I. Podolean, V. Kuncser, N. Gheorghe, D. Macovei, V. I. Parvulescu, S. M. Coman, Green Chem. 2013, 15, 3077-3082.

[144] S. Dutta, L. Wu, M. Mascal, Green Chem. 2015, 17, 2335-2338.

[145] J. G. Zeikus, Annu. Rev. Microbiol. 1980, 34, 423-464.

[146] J. Akhtar, A. Idris, R. Abd. Aziz, Appl. Microbiol. Biotechnol. 2014, 98 $987-1000$

[147] J. B. McKinlay, C. Vieille, Metab. Eng. 2008, 10, 55-68.

[148] H. Song, S. Y. Lee, Enzyme Microb. Technol. 2006, 39, 352-361.

[149] F. A. Pesa, A. M. Graham, (Standard Oil Co., Cleveland, OH, US), US4390639A, 1981.

[150] G. Chichery, P. Perras, (Rhône-Poulenc S.A., Paris, FR), US3448118A, 1969.

[151] Y. Hernandez, V. Nicolosi, M. Lotya, F. M. Blighe, Z. Sun, S. De, I. T. McGovern, B. Holland, M. Byrne, Y. K. Gun'Ko, J. J. Boland, P. Niraj, G. Duesberg, S. Krishnamurthy, R. Goodhue, J. Hutchison, V. Scardaci, A. C. Ferrari, J. N. Coleman, Nat. Nanotechnol. 2008, 3, 563-568.

[152] M. Lotya, Y. Hernandez, P. J. King, R. J. Smith, V. Nicolosi, L. S. Karlsson, F. M. Blighe, S. De, Z. Wang, I. T. McGovern, G. S. Duesberg, J. N. Coleman, J. Am. Chem. Soc. 2009, 131, 3611-3620.

[153] J. N. Coleman, Acc. Chem. Res. 2013, 46, 14-22.

[154] J. A. Moore, T. Tannahill, High Perform. Polym. 2001, 13, S305-S316.

[155] J. J. Bozell, D. C. Elliott, Y. Wang, G. G. Neuenscwander, S. W. Fitzpatrick, R. J. Bilski, J. L. Jarnefeld, Resour. Conserv. Recycl. 2000, 28, 227-239.

[156] Y. Guo, K. Li, X. Yu, J. H. Clark, Appl. Catal. B 2008, 81, 182-191. 
[157] R. V. Smith, (S. C. Johnson \& Son, Inc., Racine, WI, US), US3248421A, 1966.

[158] S. Van de Vyver, J. Geboers, S. Helsen, F. Yu, J. Thomas, M. Smet, W. Dehaen, B. F. Sels, Chem. Commun. 2012, 48, 3497-3499.

[159] X. Yu, Y. Guo, K. Li, X. Yang, L. Xu, Y. Guo, J. Hu, J. Mol. Catal. A 2008, 290, 44-53.

[160] J. Wang, S. Jaenicke, G.-K. Chuah, RSC Adv. 2014, 4, 13481-13489.

[161] J. C. Serrano-Ruiz, R. M. West, J. A. Durnesic, Annu. Rev. Chem. Biomol. Eng. 2010, 1, 79-100.

[162] R. Cao, J. Xin, Z. Zhang, Z. Liu, X. Lu, B. Ren, S. Zhang, ACS Sustainable Chem. Eng. 2014, 2, $902-909$.

[163] M. Mascal, S. Dutta, I. Gandarias, Angew. Chem. Int. Ed. 2014, 53, 1854 1857; Angew. Chem. 2014, 126, 1885-1888.

[164] D. M. Alonso, S. G. Wettstein, J. A. Dumesic, Green Chem. 2013, 15, $584-595$.

[165] K. Yan, Y. Yang, J. Chai, Y. Lu, Appl. Catal. B 2015, 179, 292-304.

[166] S. De, B. Saha, R. Luque, Bioresour. Technol. 2015, 178, 108-118.

[167] X. Tang, X. Zeng, Z. Li, L. Hu, Y. Sun, S. Liu, T. Lei, L. Lin, Renewable Sustainable Energy Rev. 2014, 40, 608-620.

[168] M. Chalid, A. A. Broekhuis, H. J. Heeres, J. Mol. Catal. A 2011, 341, 14 21.

[169] E. Fache, C. Santini, F. Senocq, J. M. Basset, J. Mol. Catal. 1992, 72, $331-336$.

[170] K. Nuithitikul, M. Winterbottom, Catal. Today 2007, 128, 74-79.

[171] R. S. Assary, L. A. Curtiss, Chem. Phys. Lett. 2012, 541, $21-26$.

[172] R. A. Bourne, J. G. Stevens, J. Ke, M. Poliakoff, Chem. Commun. 2007, $4632-4634$.

[173] W. Luo, U. Deka, A. M. Beale, E. R. H. van Eck, P. C. A. Bruijnincx, B. M. Weckhuysen, J. Catal. 2013, 301, 175-186.

[174] W. Luo, P. C. A. Bruijnincx, B. M. Weckhuysen, J. Catal. 2014, 320, $33-$ 41.

[175] C. Ortiz-Cervantes, J. J. García, Inorg. Chim. Acta 2013, 397, 124-128.

[176] Y. Yao, Z. Wang, S. Zhao, D. Wang, Z. Wu, M. Zhang, Catal. Today 2014, 234, 245-250.

[177] M. Sudhakar, M. Lakshmi Kantam, V. Swarna Jaya, R. Kishore, K. V. Ramanujachary, A. Venugopal, Catal. Commun. 2014, 50, 101-104.

[178] K. Yan, T. Lafleur, G. Wu, J. Liao, C. Ceng, X. Xie, Appl. Catal. A 2013, $468,52-58$.
[179] K. Yan, T. Lafleur, C. Jarvis, G. Wu, J. Cleaner Prod. 2014, 72, 230-232.

[180] K. Yan, A. Chen, Fuel 2014, 115, $101-108$.

[181] K. Yan, A. Chen, Energy 2013, 58, 357-363.

[182] A. M. Hengne, C. V. Rode, Green Chem. 2012, 14, 1064-1072.

[183] M. Chia, J. A. Dumesic, Chem. Commun. 2011, 47, 12233-12235.

[184] W. R. H. Wright, R. Palkovits, ChemSusChem 2012, 5, 1657-1667.

[185] T. E. Graedel, Annu. Rev. Mater. Res. 2011, 41, 323-335.

[186] M. D. Gerst, T. E. Graedel, Environ. Sci. Technol. 2008, 42, 7038-7045.

[187] L. Erdmann, T. E. Graedel, Environ. Sci. Technol. 2011, 45, 7620-7630.

[188] B. K. Reck, T. E. Graedel, Science 2012, 337, 690-695.

[189] W.-Q. Chen, T. E. Graedel, Environ. Sci. Technol. 2012, 46, 8574-8586.

[190] I. T. Horváth, H. Mehdi, V. Fábos, L. Boda, L. T. Mika, Green Chem. 2008, $10,238-242$.

[191] M. G. Al-Shaal, A. Dzierbinski, R. Palkovits, Green Chem. 2014, 16, $1358-1364$.

[192] X.-L. Du, Q.-Y. Bi, Y.-M. Liu, Y. Cao, H.-Y. He, K.-N. Fan, Green Chem. 2012, 14, $935-939$.

[193] D. C. Elliott, J. G. Frye, (Battelle Memorial Institute, Columbus, OH, US), US5883266A, 1999.

[194] F. M. A. Geilen, B. Engendahl, A. Harwardt, W. Marquardt, J. Klankermayer, W. Leitner, Angew. Chem. Int. Ed. 2010, 49, 5510-5514; Angew. Chem. 2010, 122, 5642-5646.

[195] J.-P. Lange, R. Price, P. M. Ayoub, J. Louis, L. Petrus, L. Clarke, H. Gosselink, Angew. Chem. Int. Ed. 2010, 49, 4479-4483; Angew. Chem. 2010, 122, $4581-4585$.

[196] C. E. Chan-Thaw, M. Marelli, R. Psaro, N. Ravasio, F. Zaccheria, RSC Adv. 2013, 3, 1302-1306.

[197] J. C. Serrano-Ruiz, D. Wang, J. A. Dumesic, Green Chem. 2010, 12, $574-$ 577.

[198] J. C. Serrano-Ruiz, D. J. Braden, R. M. West, J. A. Dumesic, Appl. Catal. B 2010, 100, 184-189.

[199] L. E. Manzer, Appl. Catal. A 2004, 272, 249-256.

Received: October 18, 2015

Published online on 0000 


\section{REVIEWS}

F. D. Pileidis, M.-M. Titirici*

$\mathbf{\square}-\mathbf{\square}$

Levulinic Acid Biorefineries: New Challenges for Efficient Utilization of Biomass
Refined and ready: Lignocellulosic biomass upgrade through the use of levulinic acid offers a wide array of products with a variety of applications ranging from fuel additives to biobased chemicals, green solvents, biopolymers, and biofertilizers. 